\title{
Update in Parkinson's Disease
}

\author{
Fátima Carrillo and Pablo Mir \\ Unidad de Trastornos del Movimiento. Servicio de Neurología. Instituto de Biomedicina de \\ Sevilla (IBiS). Hospital Universitario Virgen del Rocío/CSIC/Universidad de Sevilla, \\ Spain
}

\section{Introduction}

Parkinson's disease (PD) was first described in 1817 by James Parkinson, who described in his monograph entitled "An Essay on the Shaking Palsy" the description of the clinical features of this disease (Parkinson, 1817). The cardinal clinical manifestations of PD are resting tremor, rigidity, bradykinesia, and gait dysfunction. It is now appreciated that PD is also associated with many nonmotor features, including autonomic dysfunction, pain and sensory disturbances, mood disorders, sleep impairment, and dementia (Olanow et al, 2009). $\mathrm{PD}$ is the second most common neurodegenerative disorder, with an average age at onset of about 60 years and the mean duration of the disease from diagnosis to death is 15 years, with a mortality ratio of 2 to 1 (Katzenschlager et al, 2008). The incidence of the disease rises steeply with age, from 17 - 4 in 100000 person years between 50 and 59 years of age to $93-1$ in 100000 person years between 70 and 79 years, with a lifetime risk of developing the disease of 1 - 5\% (De Rijk et al, 1995). With the aging of the population and the substantial increase in the number of at-risk individuals older than 60 years, it is anticipated that the prevalence of PD will increase dramatically in the coming decades (De Lau and Breteler, 2006).

The etiology remains obscure but important genetic and pathological clues have recently been found. This monograph is designed to make a comprehensive review of all aspects of both clinical as pathophysiological and therapeutic concerning PD, as well as an update on the innovative aspects of the disease primarily focused on identifying new genetic factors and new outlook therapeutics.

\section{Neuropathology}

Pathologically, PD is characterized by degeneration of dopaminergic neurons in the substantia nigra pars compacta (SNc). However, cell loss in the locus coeruleus, dorsal nuclei of the vagus, raphe nuclei, nucleus basalis of Meynert, and some other catecholaminergic brain stem structures including the ventrotegmental area also exists (Damier et al, 1999). This nerve-cell loss is accompanied by three distinctive intraneuronal inclusions: the Lewy body, the pale body, and the Lewy neurite. A constant proportion of nigral neurons (3-4\%) contain Lewy bodies, irrespective of disease duration. This finding is consistent with the notion that Lewy bodies are continuously forming and disappearing in the diseased substantia nigra (Greffard et al, 2010). The brain-stem shape is a spherical 
structure measuring $8-30 \mu \mathrm{m}$ with a hyaline core surrounded by a peripheral pale-staining halo, and is composed ultrastructurally of 7-20-nm wide filaments with dense granular material and vesicular structures. Pale bodies are large rounded eosinophilic structures that often displace neuromelanin and are the predecessor of the Lewy body.

Aggregated a-synuclein is the main component of Lewy bodies in dopaminergic neurons of all PD patients, including those in whom PD occurred sporadically. Aggregated a-synuclein in the cytosol of cells does not only occur in the Substantia nigra but already earlier, presymptomatically in the motor part of the Nucleus vagus, in the olfactory bulb and in the Locus coeruleus. In later stages cortical areas of the brain are also frequently involved (Braak and Tredici, 2010). In fact, these bodies are present in small numbers in almost all cases of PD (Halliday et al, 2008). Neocortical Lewy bodies are not necessarily the pathological correlate of dementia in PD (Colosimo et al, 2003; Parkkinen et al, 2005). The amount of associated cortical $\beta$-amyloid seems to be the key factor for the cognitive decline in PD (Holton et al, 2008; Halliday et al, 2008). The hypothesis that the aggregation of a-synuclein and the build up of Lewy bodies results in toxicity has been challenged.

Currently, most evidence indicates that oligomers but not the fibrils of a-synuclein that are deposited in the Lewy bodies, are the toxic species. This would also imply that the rapid conversion of a-synuclein from an oligomeric to an aggregated state, deposited in Lewy bodies, may help to detoxify the oligomeric form of a-synuclein (Goldberg and Lansbury, 2000). Fetal mesencephalic neurons implanted in patients with PD to restore dopaminergic transmission may develop Lewy bodies. The existence of different striatal level factors present in the striatal microenvironment of the host probably triggers the propagation of alpha- asynuclein pathology. Inflammation, oxidative stress, excitotoxicity, and loss of neurotrophic support of the grafted neurons could all be important factors (Li et al, 2008, 2010). A prion hypothesis implicating permissive templating has also been proposed (Hardy 2005).

The few patients with PD of genetic origin (a-synuclein, LRRK-2, and GBA mutations) who have had autopsy have all shown changes indistinguishable from those found in patients with PD (Lees et al, 2008). Some families with $L R R K-2$ mutations also have tangle pathology and non-specific neuronal loss (Gilks et al, 2005). In contrast, parkin mutations lead to nigral loss, restricted brain-stem neuronal loss, and absence of associated Lewy bodies or neurofibrillary degeneration. Heterozygous parkin carriers, however, have been associated with both Lewy body and neurofibrillary tangle pathology (Van de Warrenburg et al, 2001; Pramstaller et al, 2005).

\section{Genetic of Parkinson's disease}

The PD is mostly idiopathic. However, at present, genetics has taken a very important role in clinical diagnosis. The first genetic contribution to PD was made by William Richard Gowers, in 1902, with the observation of familial aggregation in some patients with PD, but it was not until 1997 that discovered the first gene mutation associated with it (SNCA/asynuclein).

Today there are two kinds of Mendelian PD: autosomal dominant and autosomal recessive PD. Generally, the recessive autosomal forms are associated with PD onset age of juvenile (age of onset $<40$ years) and an unknown condition. Parkin (PRKN) is the most frequently mutated gene in early-onset PD. Dominant autosomal PD is later onset, usually appears between 50-60 years of age, and pathologically with Lewy bodies. LRRK2 is the most frequently mutated gene in dominant PD (Lees et al, 2009). 
Mutations in the glucocerebrosidase gene (GBA) are associated with Gaucher's disease, the most common lysosomal storage disorder. Parkinsonism is an established feature of Gaucher's disease and an increased frequency of mutations in GBA has been reported in several different ethnic series with sporadic PD. Heterozygous mutations in the GBA gene significantly increased (five times) the risk of PD (Sidransky et al, 2009). In addition, patients with heterozygous mutations in the GBA gene also have pathology similar to idiopathic PD, with the presence of Lewy bodies and a-synuclein aggregate. GBA mutations represent a significant risk factor for the development of PD and suggest that to date, this is the most common genetic factor identified for the disease (Neumann et al, 2009).

\subsection{Autosomal dominant forms of Parkinson's disease}

To date, there are two genes associated with dominant autosomal dominant PD: SNCA/asynuclein (PARK1) and leucine rich repeat kinase 2 (LRRK2, PARK8).

\subsubsection{SNCA/a-synuclein (PARK1)}

SNCA located on chromosome 4q21 (PARK1) was the first gene associated with PD. First, mutations in this gene were identified in families of Greek and Italian origin in 1997 (Polymeropoulos et al, 1997). This discovery was very important, because the identification of mutations in this gene was the first evidence that PD could be due to a genetic cause. After the discovery of the first pathogenic mutation, p.Ala53Thr (Polymeropoulos et al, 1997), two mutations were identified in the SNCA gene: mutation in a German family p.Ala30Pro (Kruger et al, 1998) and p.Glu46Lys mutation in a Spanish family (Zarranz et al, 2004). Years later, in 2003, was discovered the first affecting the genomic triplication of SNCA locus in a large family with PD (known as the 'Iowa kindred') (Singleton et al, 2003). After identification of the SNCA triplication, duplication SNCA genomic locus have also been identified in familial and sporadic forms of PD (Chartier-Harlin et al, 2004).

The SNCA gene encodes a protein called a-synuclein. This protein consists of 140 amino acids and is highly expressed in the central nervous system. a-Synuclein is the major fibrillar component of the Lewy body (Spillantini et al, 1997). Although its function is still unknown, appears to be involved in synaptic plasticity, neuronal differentiation, and axonal transport and synaptic vesicles (Biskup et al, 2008).

Symptoms caused by mutations in the SNCA gene are variable, but usually comes with age at onset around 50 years and phenotypic characteristics common to Lewy body dementia, with deposits of a-synuclein fibril and / or protein Tau, where Lewy bodies are more distributed throughout the brain of what we usually see in the PD. Some patients have dementia, visual hallucinations, parkinsonism and fluctuating cognition and attention (for example, patients with the mutation p.Glu46Lys and SNCA locus triplication). In contrast, the families described with duplication of the SNCA locus appear to have a slower progression of the disease, age of onset is usually late and not have dementia (Hardy et al, 2009). These latter observations led to suggest that the evolution of the disease may be associated with a dose-related effect of the SNCA locus (Singleton et al, 2003).

\subsubsection{LRRK2/Dardarin (PARK 8)}

Another locus for a dominant form of PD was first mapped in a Japanese family on chromosome 12 and named PARK8 (Funayama et al, 2002). Missense mutations in the gene for LRRK2 were found to be disease causing in 2004 (Paisan-Ruiz et al, 2004; Zimprich et al, 
2004). The most common mutation is the p.Gly2019Ser, which also constitutes the most common mutation of both mendelian and sporadic PD (Healy et al, 2008). Although there are over 50 different mutations described in the gene for confirmation dardarin pathogenicity in some of these mutations are difficult (Paisán-Ruiz 2009).

LRRK2 contains 51 coding exons and encodes a protein of 2,257 amino acids called dardarin. Endogenous LRRK2 is ubiquitiously expressed within neurons and associates with membranes and lipid rafts. The protein is found in presynaptic terminals where it associates with vesicles and endosomes (Biskup et al, 2008). Its function remains unknown, although functional studies have found that certain mutants alter LRRK2 kinase activity and this activity is crucial for the toxic effect of the protein. It has also been seen that certain LRRK2 gene mutations cause neuronal death (Biskup et al, 2008). It is also believed that dardarin could be involved in vesicular traffic system (Shin et al, 2008).

Mutations in the LRRK2 gene vary greatly depending on the patient's geographical origin. There is some ethnic influence in the changes associated with the gene LRRK2. p.Arg1628Pro and p.Gly2385Arg as mutations, which, being absent in the Caucasian population, significantly increase the risk of PD in Asian populations. Both mutations are present in the normal population with a frequency of $2.65 \%$ (p.Arg1628Pro) and $1.8 \%$ (p.Gly2385Arg), but its prevalence is significantly higher in patients with PD. In addition, the mutation p.Gly2019Ser, common in the Caucasian population, is rarely identified in the Asian population $(<0.1 \%)$, however, two mutations adjacent to amino p.Gly2019, p.Ile2012Thr and p.Ile2020Thr, occur more frequently in Asians than in Caucasians (PaisánRuiz 2009).

The clinical presentation closely resembles sporadicPD, but patients tend to have a slightly more benign course and are less likely to develop dementia and a favorable response to treatment with levodopa. Unilateral tremor is usually the first symptom of the disease, progressing slowly and benign. Patients with mutations in the LRRK2 gene are prone to develop dystonia (Healy et al, 2008). The age of onset is very variable (from 28 to 90 years old), but with an average age approaching 60 years. A person who inherits the Gly2019Ser mutation has only $28 \%$ risk of developing parkinsonism when younger than 60 years of age, but the risk rises to $74 \%$ at 79 years of age (Paisán-Ruiz 2009). p.Gly2019Ser mutation carriers have been described with no parkinsonian symptoms, suggesting the existence of incomplete penetrance associated with this mutation, and homozygous carriers without additional clinical effect caused by gene dosage (Paisán-Ruiz 2009).

\subsection{Autosomal recessive forms of Parkinson's disease}

Loss-of-function mutations in four genes (PRKN, DJ-1, PINK1, and ATP13A2) cause early onset recessive parkinsonism (age of onset $<40$ years). Parkin mutations are the second most common genetic cause of L-dopa-responsive parkinsonism, whereas mutations in the other three genes are rare.

\subsubsection{PRKN/parkin (PARK2)}

The PARK2 locus was cloned by extensive linkage analysis conducted in 13 consanguineous families from Japan in 1997. Today, mutations (> 100 different mutations) in the PRKN gene are the most common genetic cause of early-onset parkinsonism (onset age $<40$ years). The clinical picture associated with mutations in this gene is also similar to idiopathic PD, with a slow disease progression and response generally appropiate to treatment with levodopa. 
Patients often develop dyskinesias at low doses of levodopa and generally develop dystonia. Lewy bodies are usually not a common pathology (Khan et al, 2003).

Parkin protein localizes, although not predominantly, to the synapse and associates with membranes. In general parkin is a cytoplasmic protein and functions in the cellular ubiquitination/ protein degradation pathway as an ubiquitin ligase (Kubo et al, 2001).

\subsubsection{PINK1/PTEN-induced putative kinase 1(PARK6)}

Initially, the PARK6 locus was cloned in a large Sicilian family in 2001. Three years later, pathogenic mutations in a gene called PINK1 were identified in several Italian families (Valente et al, 2004). Symptoms caused by this gene are very similar to that described in patients with mutations in the PRKN gene. However, the age of onset may be more variable, reaching present even at 68 years of age, but typically has a juvenile onset (Kumazawa et al, 2008).

PINK1 encodes a primarily mitochondrial protein kinase. Mutations in the PINK1-gene are much less common than parkin mutations, and probably account for only 1 to $4 \%$ of earlyonset cases (Valente et al, 2004; Kumazawa et al, 2008; Rogaeva et al, 2004).

\subsubsection{DJ-1 (PARK7)}

Mutations in the DJ-1 gene (PARK7) are another rare cause of recessive autosomal parkinsonism (Bonifati et al, 2003; Hedrich et al, 2004). The clinical picture with early-onset and slow progression is similar to other recessive autosomal forms of PD. The normal function of DJ-1 and its role in dopamine cell degeneration is unknown, but there is evidence linking DJ-1 to oxidative stress response and mitochondrial function (Hardy et al, 2009).

\subsubsection{ATP13A2-5P-type ATPase (PARK9)}

The locus PARK9, ATP13A2 was first identified in families of Chilean and Jordanian origin who had a syndrome known as Kufor-Rakeb. This disease is rare and presents with a rigid and akinetic parkinsonism and juvenile onset. Spasticity, Babinski signs, supranuclear gaze palsy and cognitive impairment are some of the clinical symptoms that often occur in this disease (Paisán-Ruiz et al, 2010). The gene encodes a protein lysosomal of 1,180 amino acids that are abundantly expressed in the brain and might act in the proteolytic degradation carried out in the lysosomes (Ramirez et al, 2006).

\subsubsection{Other autosomal recessive forms of parkinsonism}

Recently, mutations in the gene PLA2G6 (phospholipaseA2 calcium-independent)(PARK 14) were also found present in individuals who had an akinetic and progressive parkinsonism. Cognitive impairment is a clinical symptom that often accompanies these patients. PLA2G6 encodes a phospholipase enzyme of 752 amino acids. In general, the phospholipases induce changes in the composition of the membrane, activate the inflammatory cascade and alter cell signaling pathways of unknown function (Paisán-Ruiz et al, 2010).

Several familial cases with a complex parkinsonism and dystonia have been identified with mutations in the gene FBX07 (PARK15). The clinical features resembling parkinsonism caused by mutations in the PRKN gene. In fact, FBXO7 gene encodes a protein of 522 amino acids, which seems to be also involved in the system of ubiquitin-proteasome protein degradation (Di Fonzo et al, 2009; Paisán-Ruiz et al, 2010). 
Recently, it has been shown that patients with mutations in the gene spatacsin (SPG11) (Non PARK locus) develop a juvenile parkinsonism similar to that caused by genes ATP13A2, PLA2G6 and FBX07. These patients show a thinning of the corpus callosum, very characteristic signs of spastic paraplegia. The presenting symptoms of the disease are often both spasticity and parkinsonism (Paisán-Ruiz et al, 2010).

\section{Clinical features}

PD commonly presents with impairment of dexterity or, less commonly, with a slight dragging of one foot. The onset is gradual and the earliest symptoms might be unnoticed or misinterpreted for a long time. Fatigue and stiffness are common but non-specific complaints. Other initial symptoms are lugubrious stiff face, a hangdog appearance, a flexion of one arm with lack of swing, a monotonous quality to the speech, and an extreme slowing down. The early physical signs are often erroneously and a lag of $2-3$ years from the first symptoms to diagnosis is not unusual. A change in a patient's writing can be present for several years before diagnosis, with a tendency to slope usually in an upward direction and for the writing to get progressively smaller and more cramped after a line or two (Lee et al, 2009).

Complaints within the first 2 years of the disease of falls (especially backwards), fainting, urinary incontinence, prominent speech, disturbed swallowing, amnesia, or delirium should raise the possibility of an alternative diagnosis.

In the late stages of $\mathrm{PD}$, the face of patients is masked and expressionless, the speech is monotonous, festinant, and slightly slurred, and posture is flexed simian with a severe pill rolling tremor of the hands. Freezing of gait for several seconds can happen when attempting to enter the consulting room and, when starting to move again, the patient tends to move all in one piece with a rapid propulsive shuffle. These motor blocks lead to falls. All dextrous movements are done slowly and awkwardly, and assistance might be needed for dressing, feeding, bathing, getting out of chairs, and turning in bed. Constipation, chewing and swallowing difficulties, drooling of saliva, and urge incontinence of urine are common complaints.

Although PD has long been considered primarily a motor disorder Nonmotor symptoms (NMS) in PD are common and were recognized by James Parkinson himself. Thus, in his Essay on the Shaking Palsy in 1817, he referred to sleep disturbance, constipation, urinary incontinence and delirium (Parkinson, 1817). Numerous studies have now indicated that NMS is an integral symptom complex of PD, affecting memory, bladder and bowel, and sleep among others (Table 1) (Chaudhuri et al, 2006). It is commonly thought that NMS occur only in late or advanced PD but NMS can indeed present at any stage of the disease including early and pre-motor phase of PD. Several NMS of PD such as olfactory problems, constipation, depression and erectile dysfunction may predate the motor signs, symptoms and diagnosis of PD by a number of years (Chaudhuri et al, 2006; Tolosa et al, 2007).

Patients with PD are prone to have sleep disturbances that result in excessive daytime somnolence (EDS) and require proper identification and treatment (Comella, 2007). Sleep dysfunction in PD is usually manifest by difficulty in initiating sleep, fragmented sleep, REM behavior disorder (RBD), reversal of the sleep cycle, and EDS (Porter et al, 2008). It is possible that RBD might be early features of PD that antecede the onset of the classic motor features of the disease. In fact, in one study, RBD was found to have preceded the onset of PD symptoms in 52\% of patients (Postuma et al, 2006). RBD in patients with PD is 
frequently seen in association with visual hallucinations (Meral et al, 2007). The presence of RBD in patients with PD is also frequently associated with neuropsychiatric problems and cognitive impairment. Even the presence of RBD in a patient with PD without dementia predicts the subsequent development of cognitive impairment (Vendette et al, 2007).

Although, troublesome dysautonomia is recognized in advanced PD, cardiac (123)Imetaiodobenzylguanidine (MIBG) imaging demonstrates early cardiac sympathetic denervation in PD (low cardiac uptake) and not multiple system atrophy (MSA) where the heart is usually visualized (Goldstein et al, 2000). Cardiac sympathetic denervation has also been found in genetic forms of PD with alpha synuclein mutation (Singleton et al, 2004).

Neuropsychiatric problems such as dementia, delirium, anxiety, and depression occur at one time or another in most patients, and can potentially be more disabling than motor dysfunction.

Risk of dementia exists, particularly in those patients who present with prominent gait and speech disorders, depression, and a poor response to L-dopa. The greatest risk factor for dementia, however, is the age of the patient and not the duration of the disease (Levy, 2007). Visuospatial difficulties, disturbances of attention and vigilance, delirium, and executive dysfunction are more common in PD than in Alzheimer's disease (Noe et al, 2004). Visual hallucinations are commonly associated with PD dementia.

Depression is pervasive in PD and affects approximately $40 \%$ of patients at least once during the course of their disease (Starkstein et al, 1992). Studies have suggested that symptoms of depression may precede the development of PD.

\section{Pharmacologic treatment}

\subsection{Neuroprotection}

Several putative neuroprotective agents have been tested in placebo-controlled clinical trials. Some clinical trials had negative outcomes despite promising theoretical or preclinical evidence. These include the antioxidant vitamin E (Parkinson Study Group, 1993), the glutamate release inhibitor riluzole (Jankovic and Hunter, 2002) , coenzyme Q10 (Shults et al, 2002), glial cell line-derived neurotrophic factor (GDNF) (Nutt et al, 2003), the antiapoptotic agents TCH346 (Olanow et al, 2006), CEP-1437 (Parkinson Study Group, 2007), and the neuroimmunophilins (Gold and Nutt, 2002) which are thought to act via a possible trophic mechanism. Conversely, some putative neuroprotective agents have demonstrated significant benefits compared with controls, but still could not be unequivocally deemed to be neuroprotective because of the possibility of confounding symptomatic or pharmacologic effects. Although it is not possible to claim with certainty that any of these drugs are neuroprotective, many are routinely used by physicians based on the hope that they might slow disease progression. These agents are considered below.

\subsubsection{Selegiline}

Selegiline is a selective, irreversible inhibitor of monoamine oxidase-B (MAO-B). Selegiline was the first drug to be tested as a putative neuroprotective therapy in patients with PD based on its capacity to protect dopamine neurons by inhibiting the MAO-B oxidation of MPTP and blocking the formation of free radicals derived from the oxidative metabolism of dopamine (Olanow 1996). The initial advantages shown by selegiline have not been maintained. Furthermore, evidence is insufficient to make a conclusion on the neuroprotective, as opposed to the symptomatic effect of selegiline in PD (Parkinson Study Group, 1996). 


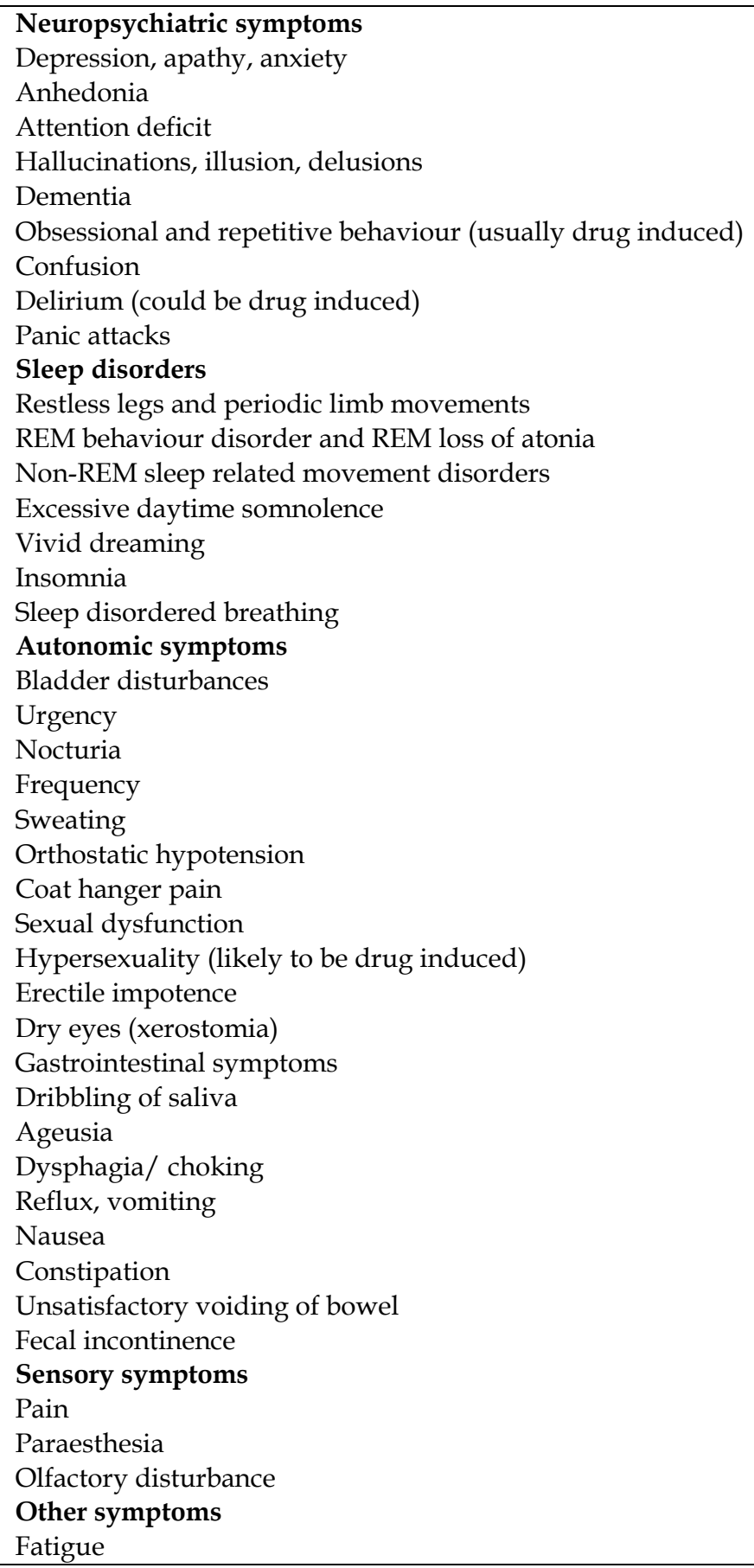




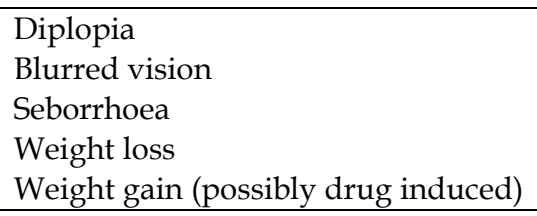

Table 1. Nonmotor features of PD

\subsubsection{Rasagiline}

Rasagiline is another selective, irreversible MAO-B inhibitor. There are data from studies in vitro and in animal models have shown neuroprotective capacity by rasagiline (Sagi et al, 2007; Zhu et al, 2008).

To test for a possible neuroprotective effect in patients with PD, rasagilina had been shown to have a symptomatic effect in the TEMPO study (The Rasagiline Mesylate in Early Monotherapy for PD Outpatients) (Parkinson Study Group, 2002). ADAGIO (the Effect of Rasagiline Mesylate in Early PD patients) study was designed to verify these results. It demonstrated that early treatment with rasagiline $1 \mathrm{mg}$ daily provided a benefit that was not obtained with the delayed introduction of the drug. These results are consistent with rasagiline having a possible neuroprotective effect (Olanow et al, 2009).

\subsubsection{Dopamine agonist}

Dopamine agonists have been studied for putative neuroprotective effects in PD, based on their capacity to protect dopamine neurons from a variety of toxins (Schapira, 2002). Indeed, the dopamine agonist pramipexole has been reported to protect dopamine neurons in MPTP-lesioned primates (Iravani et al, 2006).

Clinical trials have attempted to test the capacity of dopamine agonists to provide diseasemodifying effects in PD. However, Class I randomized, controlled trials with bromocriptine (Olanow et al, 1995), pramipexol (Parkinson Study Group, 2000; Parkinson Study Group, 2002), and ropinirole (Rakshi et al, 2002; Whone et al, 2003) produced no convincing evidence of neuroprotection in early PD.

\subsubsection{Levodopa}

The only available placebo-controlled study of levodopa in relation to neuroprotection is inconclusive about any Neuroprotective, as opposed to symptomatic effect (Fahn et al, 2004). Mortality studies suggest improved survival with levodopa therapy (Rajput 2001).

\subsection{Motor symptoms treatment of PD}

\subsubsection{Levodopa}

Levodopa is the most effective drug for the symptomatic treatment of PD and the gold standard against which new therapies must be measured. Benefits are usually seen in all stages of the disease and can be particularly noteworthy in patients with early PD, in whom the drug can control virtually all of the classic motor features. Although prediction of the therapeutic response in an individual is not possible, motor symptoms initially improve by $20-70 \%$. Speech, swallowing, and postural instability can improve initially, but axial symptoms are generally less responsive and seem to escape more readily from long-term control (Fahn et al, 2004). 
Levodopa exerts its symptomatic benefits through conversion to dopamine, and is routinely administered in combination with a decarboxylase inhibitor (carbidopa, benserazide) to prevent its peripheral conversion to dopamine and the resultant nausea, vomiting and orthostatic hypotension. A combination of carbidopa/levodopa and the COMT inhibitor entacapone is available. There are also sustained-release formulations of levodopa although sustained-release formulations of levodopa are not as well absorbed as regular formulations, and doses $20 \%$ to $30 \%$ higher may be necessary to achieve the same clinical effect. A gel preparation of levodopa (Duodopa) has been used for intraintestinal infusion of the agent and is used in more advanced stages of disease.

Levodopa is absorbed in the small bowel by active transport through the large neutral amino acid (LNAA) pathway, and can be impaired by alterations in gastrointestinal motility and by dietary LNAAs, such as phenylalanine, leucine, and valine, which compete with levodopa for absorption through the LNAA (Nutt et al, 1984).

Acute side effects associated with levodopa include nausea, vomiting, and hypotension, but levodopa is generally well tolerated when it is gradually increased. Levodopa is generally started at a low dose to minimize these risks. Most people can be maintained over the first 5 years of the disease on $300-600 \mathrm{mg} /$ day levodopa. Levodopa maintain a similar level of control in de novo PD after 5 years (Koller et al, 1999), and also in more advanced PD with a duration of about 10 years and without motor fluctuations(Goetz et al, 1988).

Chronic levodopa therapy is associated with motor complications, such as dyskinesias and motor fluctuations, in the majority of patients. Motor fluctuations include delayed onset of levodopa's therapeutic effect or its wearing off between doses. Dyskinesias are involuntary choreiform movements that can involve any part of the body and sometimes impose disabling or painful postures. A meta-analysis found $40 \%$ likelihood of motor fluctuations and dyskinesias after 4-6 years of levodopa therapy (Ahlskog and Muenter, 2001). Risk factors are younger age, longer disease duration, and levodopa (Denny AP and Behari M, 1999; Fahn et al, 2004). In individual studies, the percentage of fluctuations and dyskinesia may range from $10 \%$ to $60 \%$ of patients at 5 years on disease duration, and up to $80-90 \%$ in later years (Olanow et al, 2001). Patients with PD can also experience fluctuations in such nonmotor symptoms as mood, cognition, autonomic disturbances, pain, and sensory function (Witjas et al, 2002). Levodopa may also be associated with neuropsychiatric side effects, including cognitive impairment, confusion and psychosis. Importantly, many PD features are not satisfactorily controlled by, or do not respond to, levodopa. These include freezing episodes, postural instability with falling, autonomic dysfunction, mood disorders, pain and sensory disturbances, and dementia. Levodopa treatment can also be associated with a dopamine dysregulation syndrome in which patients compulsively take extra doses of levodopa in an addictive fashion. Although levodopa has been associated with impulse control disorders (ICDs) such as hypersexuality and pathologic gambling, these behaviors have primarily been reported to be associated with dopamine agonists (Ceravolo et al, 2010). In addition, chronic levodopa treatment has been associated with punding, which is a series of repetitive and purposeless behaviors, such as collecting or assembling and disassembling objects for no apparent reason (Evans et al, 2004).

There has long been a theoretical concern that levodopa might accelerate neuronal degeneration in PD because of the potential of the drug to generate free radicals through its oxidative metabolism (Olanow et al, 2004). However, most studies in animal models and humans do not show an accelerated loss of dopaminergic neurons to long-term levodopa therapy in usual clinical doses (Olanow et al, 2004). The Earlier vs Later Levodopa Therapy 
in PD (ELLDOPA) study was the first double-blind, placebo-controlled trial to assess the safety and efficacy of different doses of levodopa and address the potential toxicity of levodopa in patients with PD (Fahn et al, 2004). The clinical results of this study certainly do not provide any evidence to suggest that levodopa is toxic or accelerates the development of disability in patients with PD and do not demonstrate any adverse effect of levodopa on PD progression.

\subsubsection{Dopamine agonist}

Dopamine agonists are a class of drugs with diverse physical and chemical properties. They share the capacity to directly stimulate dopamine receptors, presumably because they incorporate a dopamine-like moiety within their molecular configuration. Dopamine agonists have drawn particular interest as a treatment for PD because of their potential to provide antiparkinsonian effects with a reduction in the motor complications associated with levodopa. Today, dopamine agonists are also used as early symptomatic therapy to reduce the risk of developing the motor complications associated with levodopa therapy.

It is generally accepted that the shared D2-like receptor agonistic activity produces the symptomatic antiparkinsonian effect. This D2 effect also explains peripheral (gastrointestinal nausea and vomiting), cardiovascular (orthostatic hypotension) and neuropsychiatric (somnolence, psychosis, and hallucinations) side effects.

The first group of dopamine agonists used in the treatment of PD were ergot derivatives (bromocriptine, cabergoline, lisuride, pergolide, dihidroergocriptine). Numerous studies have demonstrated the effectiveness of these agents in PD as adjuncts to levodopa and shown that as monotherapy they are associated with a reduced risk of inducing dyskinesia compared with levodopa (Montastruc et al, 1994; Bracco et al, 2004; Oertel et al, 2006). However, their use has markedly declined due to the risk of valvular fibrosis and the introduction of nonergot dopamine agonists (apomorfine, pramipexole, ropinirole, rotigotine, piribedil). Although rare, cardiac dysfunction with valvular thickening and fibrosis has been reported with pergolide and cabergoline, presumably because they activate the 5HT2b receptor (Morgan and Sethi 2006; Zanettini et al, 2007; Roth BL 2007). In the nineties, nonergot dopamine agonists have largely supplanted the ergot agonists as the dopamine agonists of choice for the treatment of PD. Apomorphine is a short-acting dopamine agonist that is available in injectable form as a rescue drug for the management of "off" periods, and in some countries as an subcutaneous infusion therapy for the management of patients with advanced motor complications.

Levodopa is more efficacious than any orally active dopamine agonist monotherapy. The proportion of patients able to remain on agonist monotherapy falls progressively over time to $<20 \%$ after 5 years of treatment. For this reason, after a few years of treatment, most patients who start on an agonist will receive levodopa as a replacement or adjunct treatment to keep control of motor parkinsonian signs. Over the last decade, a commonly tested strategy has been to start with an agonist and to add levodopa later if worsening of symptoms cannot be controlled with the agonist alone (Rinne et al, 1998; Parkinson Study Group 2000; Rascol et al, 2000).

From the limited data available (bromocriptine versus ropinirole, bromocriptine versus pergolide), the clinical relevance of the reported difference between agonists, if any, remains questionable (Mizuno Y et al, 1995; Korczyn et al, 1999).

Class I randomized, controlled trials demonstrate how early use of an agonist can reduce the incidence of motor complications versus levodopa (cabergoline (Bracco et al, 2004), 
pramipexole (Parkinson Study Group, 2000), and ropinirole (Rascol et al, 2000; Whone et al 2003). Similar conclusions were reported with bromocriptine (Montastruc et al, 1994), and pergolide (Oertel et al, 2006) in several class II studies. There is no evidence to suggest that an agonist is more effective than another in preventing or delaying the time to onset of motor complications. Dopamine agonists serve to delay the onset of motor complications by delaying the time until levodopa is required, but do not prevent motor complications once levodopa is introduced. Indeed, two studies have now shown that the time to onset of motor complications from when levodopa is introduced is the same whether levodopa is used as initial therapy or as an adjunct to the dopamine agonist (Rascol et al, 2000; Constantinescu et al, 2007).

Regarding the treatment of non-motor symptoms in PD pramipexole has shown to have an antidepressant effect in several randomized, double-blind controlled studies (Corrigan et al, 2000; Lemke et al, 2006; Bxarone et al, 2010). A recent study with transdermal rotigotine 24 hours monotherapy vs placebo has shown an improvement in nocturnal sleep disturbance (assessed by the "Modified Parkinson's Disease Sleep Scale) and early-morning motor dysfunction (Trenkwalder et al, 2011).

There are long-acting preparation of pramipexole and ropinirole with 24-hour prolonged release. Also rotigotine by transdermal administration has been shown to have constant levels of drug with a single patch daily. This allows for less fluctuation in plasma drug levels and permits drug levels to be maintained during the waking day and to drop off during the night. This may lead to better compliance and more consistent symptom response throughout the day and perhaps better nighttime symptom control. In adjunct studies, ropinirole (Pahwa et al, 2007) and pramipexol (Hauser et al, 2010) 24 hours provided improvement in UPDRS motor and quality-of-life scores comparable with the immediate release form of the drug and was well tolerated.

Dopamine agonists and all other active dopamine-mimetic medications share a common safety profile. Accordingly, side effects such as nausea, vomiting, orthostatic hypotension, confusion and psychosis, may occur with administration of any of these agents. Hallucinations and somnolence are more frequent with some agonists than with levodopa and are particularly common in elderly people or patients with cognitive impairment (Etminan et al, 2001). The ergot-derived dopamine agonists can be associated with a Raynaud's-like phenomena, erythromelalgia, and pulmonary or retroperitoneal fibrosis (Andersohn and Garbe, 2009). These events are relatively uncommon and are not seen with the nonergot dopamine agonists. Valvular fibrosis may occur in as many as $30 \%$ of patients receiving ergot-based dopamine agonists and can lead to valvular dysfunction with the need for surgical repair in extreme cases. This has resulted in withdrawal of pergolide from the market, and a marked reduction in the use of the other ergot agonists (Zanettini et al, 2007; Roth 2007). When these agents are used, it is essential that patients be periodically monitored with echocardiography to detect valvular alterations.

Sedation with EDS and possible unwanted sleep episodes has been associated with the use of dopamine agonists. Dopaminergic medications and dopamine agonists in particular, are known to have dose-related sedative side effects (Frucht et al, 1999; Ferreira et al, 2000; Paus et al, 2003).

Other problems related to the use of dopamine agonists include weight gain (possibly related to overeating) (Nireberg and Waters, 2006), edema (especially in the lower extremities) (Kleiner-Fisman G and Fisman, 2007) and a variety of ICDs, such as pathologic 
gambling, hypersexuality, and compulsive eating and shopping (Weintraub et al, 2006). Risk factors for ICDs include current use of dopamine agonists, particularly in high doses, young age of PD onset, and a premorbid or family history of ICDs or depression (Voon et al, 2006). ICDs were first identified in association with pramipexole, but have now been described with ropinirole and pergolide. Interestingly, they occur much less frequently with levodopa, although punding is primarily associated with chronic levodopa treatment. The precise mechanism whereby dopamine agonists might induce these ICDs is not known. It remains to be determined if dopamine agonists are directly responsible for inducing an ICD through a particular pattern of receptor stimulation, or if there is an underlying personality disorder that becomes clinically manifest with restoration of striatal dopaminergic tone.

\subsubsection{Catechol-O-methyltransferase (COMT) inhibitors}

Catechol-O-methyltransferase (COMT) inhibitors reduce the metabolism of levodopa, extending its plasma half-life and prolonging the action of each levodopa dose. Administration of levodopa with a COMT inhibitor increases its elimination half-life (from about 90 minutes to about 3 hours).

Two COMT inhibitors have been approved as adjuncts to levodopa for the treatment of PD; tolcapone and entacapone. Tolcapone inhibits COMT at peripheral level and to a lesser extent at the central level whereas entacapone acts only in the periphery.

COMT inhibitors are effective when administered in conjunction with levodopa and increase interdose, trough, and mean levodopa concentrations. Administration of levodopa plus a COMT inhibitor results in smoother plasma levodopa levels and more continuous brain availability compared with levodopa alone (Muller et al, 2006). Thus, administering levodopa with a COMT inhibitor has the potential to deliver levodopa to the brain in a more predictable and stable fashion, thus decreasing the fluctuations in levodopa concentrations seen when standard levodopa is administered intermittently.

Double-blind, placebo-controlled trials have demonstrated that both tolcapone and entacapone increase "on" time, decrease "off" time, and improve motor scores for patients with PD who experience motor fluctuations. Moreover, this benefit was associated with a reduction in the mean daily dose of levodopa (Kurth et al, 1997; Parkinson Study Group, 1997). Benefits have been shown to persist for 3 years or longer (Larsen et al, 2003). In general, superior clinical benefits have been achieved with tolcapone, reflecting the increased level of COMT inhibition.

Benefits with COMT inhibitors have also been observed in stable patients PD who have not yet begun to experience motor fluctuations (Waters et al, 1997; Olanow et al, 2004).

There has also been interest in the potential of COMT inhibitors to reduce the risk for motor complications associated with standard doses of levodopa (Olanow and Stocchi, 2004). This is based on the concept that intermittent doses of short-acting levodopa leads to pulsatile stimulation of dopamine receptors and motor complications. COMT inhibitors extend the elimination half-life of levodopa and thus, if administered frequently enough, might provide continuous levodopa to the brain. Although studies in monkeys showed that administration of levodopa plus the COMT inhibitor entacapone reduced dyskinesias compared with treatment with levodopa alone (Smith et al, 2005), these results have not been observed in patients. Specifically, in a recent clinical trial, Stalevo Reduction in Dyskinesia Evaluation (STRIDE-PD), which compared the time to onset and frequency of dyskinesia in levodopa-naïve PD patients who were randomized to initiate levodopa 
therapy with carbidopa/levodopa compared with carbidopa/levodopa/entacapone (Stalevo), was demonstrated that patients randomized to Stalevo had an increased frequency and a shorter time to dyskinesia than did those on standard levodopa (Stocchi et al, 2010).

COMT inhibitors increase levodopa bioavailability, and hence they increase the incidence of dopaminergic adverse reactions, including nausea, and cardiovascular and neuropsychiatric complications. Diarrhoea and urine discoloration are the most frequently reported non-dopaminergic adverse reactions. Tolcapone can elevate liver transaminases, and fatal cases of liver injury are reported (Assal et al, 1998). Currently, the drug has been reintroduced to the market in many countries, but has been imposed strict safety restrictions.

\subsubsection{MAO-B inhibitors}

Selegiline and rasagiline inhibit the action MAO-B. MAO-B prevents the breakdown of dopamine, leading to greater dopamine availability. Mechanisms besides MAO-B inhibition may also contribute to the clinical effects (Olanow, 1996). Unlike selegiline, rasagiline is not metabolized to amphetamine, and has no sympathomimetic activity.

Selegiline was initially approved as an adjunct to levodopa in patients with motor fluctuations. However, selegiline is primarily used in early disease, based on its putative neuroprotective effects (see section on Neuroprotection) and its capacity to provide mild symptomatic benefits (Parkinson Study Group 1993). When combined with levodopa, it can enhance dopaminergic side effects and lead to increased dyskinesia and neuropsychiatric problems, particularly in the elderly.

Rasagiline has been approved for use in patients with both early and advanced PD. Rasagiline is an irreversible inhibitor of MAO-B. It is more potent and more selective than selegiline, and does not generate amphetamine or methamphetamine metabolites. TEMPO study, a class I study with rasagiline, showed improvement of both the total UPDRS and the motor subscale of the UPDRS in patients treated with rasagiline versus placebo (Parkinson Study Group 2002). Recently published data on long-term efficacy of rasagiline in patients who participated in the TEMPO study, showing maintenance of rasagiline as monotherapy in about half of patients after two years of follow-up (Lew et al, 2010). In ADAGIO study early vs delayed start rasagiline 1 or $2 \mathrm{mg} /$ day were compared. The results of this study suggest that early treatment with rasagiline $1 \mathrm{mg} /$ day provides benefits that cannot be attained with later initiation of the drug, and argues for starting symptomatic treatment at an earlier time point than has conventionally been used (Olanow et al, 2009). The PRESTO (Parkinson Study Group, 2005) and LARGO (Rascol et al, 2005) study have demonstrated the benefit of rasagiline in patients with motor fluctuationes.

Safinamide is a new MAO-B inhibitor that is currently being studied as a treatment for early and advanced PD. In addition to its MAO-B inhibitor properties, it also inhibits dopamine uptake, and blocks sodium channels and glutamate release. A randomized, placebocontrolled trial of safinamide in early to midstage PD demonstrated modest antiparkinsonian effects, with benefits specifically noted in patients who were already receiving a dopamine agonist (Stocchi et al, 2004).

MAO inhibitors are generally well tolerated. Amphetamine metabolites of selegiline may induce insomnia. At the daily doses currently recommended, the risk of tyramine-induced hypertension (the cheese effect) is low. Also this reaction has not been reported with 
selective inhibitors of MAO-B (Heinonen EH and Myllylä, 1998). Concerns that the selegiline/levodopa combination increased mortality rates (Ben-Shlomo et al, 1998) have been allayed (Olanow et al, 1998). MAO inhibitors may also interfere with serotonin metabolism and induce a serotoninergic syndrome, although this reaction is rarely presented (Ritter and Alexander, 1997).

\subsubsection{Other antiparkinsonian drugs}

\subsubsection{Anticholinergics}

The precise mechanism of action of anticholinergic drugs in PD is not known although are believed to act by correcting the disequilibrium between striatal dopamine and acetyl choline activity. Some anticholinergics, e.g. benzotropine, can also block dopamine uptake in central dopaminergic neurons. The anticholinergics used to treat PD specifically block muscarinic receptors.

The use of anticholinergics has dramatically declined in the era of levodopa and dopamine agonists, but these agents are still occasionally used. Anticholinergic drugs are typically used in younger patients with PD in whom resting tremor is the dominant clinical feature and where cognitive function is preserved. Anticholinergic drugs are of little value in the treatment of other parkinsonian features such as rigidity, akinesia, gait dysfunction, or impaired postural reflexes (Cantello et al, 1986). Currently trihexyphenidyl is the most widely used of the anticholinergic drugs.

The most commonly reported side effects are blurred vision, urinary retention, nausea, constipation (rarely leading to paralytic ileus), and dry mouth. The incidence of reduced sweating, particularly in those patients on neuroleptics, can lead to fatal heat stroke. Anticholinergics are contraindicated in patients with narrow-angle glaucoma, tachycardia, hypertrophy of the prostate, gastrointestinal obstruction, and megacolon. Impaired mental function (mainly immediate memory and memory acquisition) is a well-documented central side effect that resolves after drug withdrawal. Therefore, if dementia is present, the use of anticholinergics is contraindicated (Van Herwaardenet al, 1993).

\subsubsection{Amantadine}

Amantadine's mechanism of action remains unclear. A blockade of N-methyl-D-aspartate (NMDA) glutamate receptors and an anticholinergic effect are proposed, whereas other evidence suggests an amphetamine-like action to release presynaptic dopamine stores (Kornhuber et al, 1994).

Amantadine has been shown to improve akinesia, rigidity, and tremor in placebo-controlled trials when used as monotherapy or in combination with levodopa. Early studies suggested that benefit with amantadine is transient, but some patients enjoy more sustained benefits (Butzer et al, 1975; Timberlake and Vance, 1978).

Amantadine is the only currently available agent that is capable of blocking dyskinesia without interfering with the parkinsonian response and has proven to be of considerable benefit for some patients. The utilization of amantadine, however, may be limited by its propensity to cause cognitive impairment, particularly in patients with advanced PD (Verhagen Metman et al, 1998; Metman et al, 1999).

Side effects include confusion, hallucinations, insomnia, and nightmares. These are more common in older patients, but can be seen in patients of any age. Peripheral side effects include livedo reticularis and ankle edema, although these are rarely severe enough to limit 
treatment. Dry mouth and blurred vision can occur and are presumed related to its peripheral anticholinergic effects.

\subsection{Nonmotor symptoms treatment of Parkinson's disease (Table 2)}

NMS in PD include neuropsychiatric symptoms, sleep disturbances, autonomic dysfunction, and pain or sensory problems. Such symptoms are a frequent accompaniment to the motor disability with continuing disease progression (Chaudhuri et al, 2006). Although several nondopaminergic systems within the brainstem and cortex are involved in PD, specific clinicopathological correlation for such features remains uncertain, and despite the increasing recognition of these problems, specific pharmacological therapies that target the relevant nondopaminergic neurotransmitter system are limited.

The management of dementia in PD is a pressing problem because cognitive impairment is a common and important source of disability. As dementia in PD is associated with a cholinergic deficit, trials of the cholinesterase inhibitors donepezil and rivastigmine have been carried out in patients with dementia. In these studies, both rivastigmine (Emre et al, 2004) and donepezil (Ravina et al, 2005) showed a modest but significant improvement compared with controls without worsening of parkinsonism.

The cause of psychotic symptoms in PD is probably multifactorial, involving interplay between pathological processes and dopaminergic medications. The management of hallucinations and delirium in the patient with PD must begin with a pretreatment setting eliminating those drugs that can cause hallucinations or delusions and adjusting the dose of levodopa. When the adjustments fail to eliminate or sufficiently alleviate hallucinations and/or cannot be accomplished without inducing a meaningful deterioration in PD features, neuroleptic therapy should be considered. Haloperidol, perphenazine, or chlorpromazine are effective antipsychotics, but are not recommended for patients with PD because of their capacity to block striatal dopamine D2 receptors and exacerbate parkinsonian features. The "atypical" neuroleptics are the preferred agents to use (especially clozapine (Parkinson Study Group, 1999) and quetiapine (Fernandez et al, 2003)), and can often effectively treat hallucinations and psychosis induced by dopaminergic medications. They are called "atypical" because among other factors they preferentially block limbic and cortical dopamine receptors, but are relatively devoid of D1 and D2 receptor-blocking properties (Friedman and Factor, 2000).

Anxiety and depression are extremely common in PD and frequently coexist. Both might respond to dopaminergic therapies, and anxiety in particular can be experienced when the motor effects of levodopa have worn off (ie, during an "off period). However, successful management of these mood disorders often requires treatments in addition to dopaminergic agents, which suggests that non-dopaminergic neurotransmitters are involved. The current management of depression and anxiety in PD involves the use of conventional treatments that enhance serotonergic neurotransmission, such as selective serotonin reuptake inhibitors (SSRIs) or tricyclic antidepressants. Although in clinical practice many patients with PD do experience a significant improvement in mood symptoms with these agents (whatever the exact mechanism of action), the true effectiveness in PD has not been established owing to the limited numbers of available randomised controlled trials (Weintraub et al, 2005; Chung et al, 2003). Some antidepressants, which are undergoing investigation for depression and anxiety in PD, are also selective noradrenergic reuptake inhibitors (eg, duloxetine, venlafaxine, and desipramine). 
Patients with PD can experience various behavioural problems as a consequence of dopaminergic medications, including impulse control disorders, such as pathological gambling, shopping, eating, and hypersexuality,(Voon et al, 2011) and abnormal excessive motor behaviours ranging from purposeless fiddling to complex stereotypic activities, known as "punding" (Evans et al, 2004). These problems have been particularly associated with dopamine agonists, but also with levodopa. The precise mechanism whereby dopamine agonists might induce these ICDs is not known. Treatment of each patient should be individualized based on the magnitude of the ICD problem and the need for dopaminergic drugs to control PD features. The symptoms might resolve on reducing or discontinuing the dopamine agonists, although they can persist in some patients (Mamikonyan et al, 2008). Other approaches could include trials of various psychoactive agents and psychosocial interventions and referring patients for appropriate counseling services.

Sleep dysfunction in PD is usually manifest by difficulty in initiating sleep, fragmented sleep, reversal of the sleep cycle, and EDS. Sleep disturbances in PD are multifactorial and may be related to aging, parkinsonian motor dysfunction, dyskinesia, pain, nocturia, nightmares, dopaminergic and nondopaminergic medications, cognitive impairment, and a variety of specific sleep disorders, including restless legs syndrome (RLS), periodic limb movements of sleep (PLMS), RBD, and sleep apnea. Collectively, they contribute to the increase in daytime sleepiness that is so frequently found in patients with PD (Tandberg et al, 1999; Comella, 2007). Dopaminergic medications and particularly dopamine agonists can have a complex effect on sleep. Sometimes these medications cause insomnia or sleepiness. In other situations they may improve nocturnal immobility, and in this way improve the quality of sleep (Montastruc et al, 2001; Brodsky et al, 2003). Thus, dopaminergic medications can either improve or worsen sleep in patients with PD. RBD in patients with PD may be effectively treated with low-dose clonazepam ( 0.25 to $1.0 \mathrm{mg}$ nightly). The wakepromoting drug modafinil, which possibly affects histamine release in the hypothalamus, is currently used as an option to treat excessive daytime sleepiness in patients with PD (Morgenthaler et al, 2007). Is currently being assessed two other drugs (the BF 2.649 a selective histamine $\mathrm{H} 3$ inverse agonist and the caffeine, a non-selective adenosine antagonist) in the treatment of EDS in PD patients.

Drugs currently used to treat orthostatic hypotension in PD include midodrine, a sympathomimetic, and fludrocortisone, a mineralocorticoid. Supine hypertension is a potential side-effect of both of these approaches. The acetylcholinesterase inhibitor pyridostigmine bromide has been suggested to reduce orthostatic hypotension with less effect on supine hypertension, although evidence is limited (Low and Singer, 2008). L-threo3, 4- dihydroxyphenylserine is a synthetic amino acid precursor of noradrenaline that is available for freezing of gait in PD and orthostatic hypotension in autonomic failure (Mathias et al, 2001). However, few randomised controlled trials few randomised controlled trials (RCTs) of treatment for orthostatic hypotension have been undertaken specifically in $\mathrm{PD}$, but rather have involved mixed populations of patients including multiple system atrophy, in which the pathophysiology of orthostatic hypotension is different. Thus, the true efficacy of treatments for orthostatic hypotension in PD remains unclear.

Urinary symptoms can be troublesome in advanced PD. Current treatments are drugs for overactive bladder symptoms, such as the muscarinic antagonists oxybutynin and tolterodine. However, such drugs are typically poorly tolerated in patients with advanced PD due to central and peripheral anticholinergic side-effects. Another muscarinic 
antagonist, trospium chloride, has potentially fewer central side-effects due to poor penetration of the blood - brain barrier, and is effective for treating overactive bladder symptoms (Staskin, 2006).

Postural instability is a late complication of PD which can lead to a mounting fear of falls with increasing immobilisation and dependency. Most falls in patients with PD occur in a forward or sideways direction and are due to turning difficulties, gait and postural asymmetries, problems with sensorimotor integration, difficulties with multitasking, failure of compensatory stepping, and orthostatic myoclonus (Bloem et al, 2004). Skilled physical therapy with cueing to improve gait, cognitive therapy to improve transfers, exercises to improve balance, and training to build up muscle power and increase joint mobility, is efficacious (Keus et al, 2007). Regular physical and mental exercise should be encouraged at all stages of the disease. Benzodiazepines should be avoided wherever possible because they increase the risk of falling.

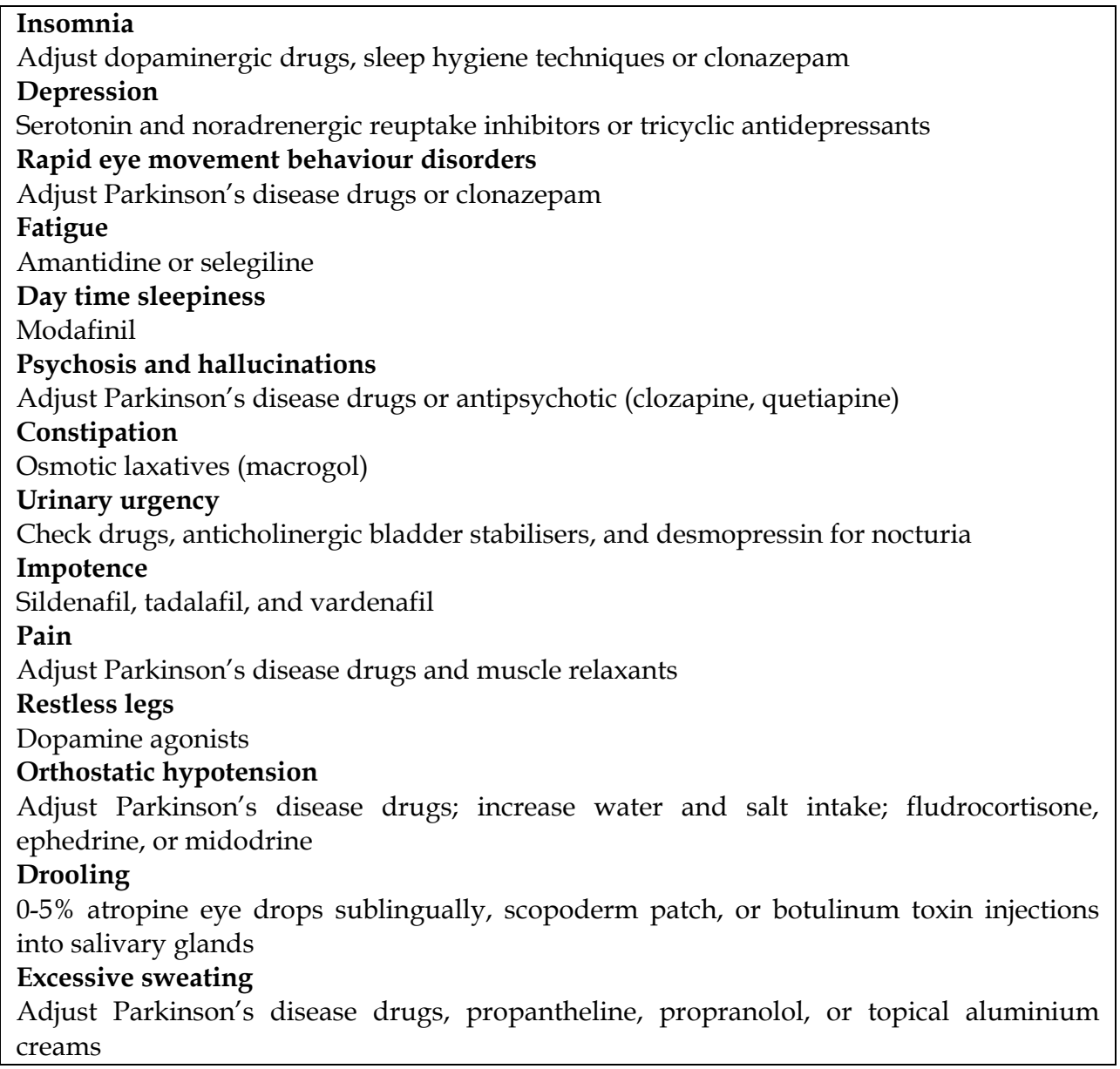

Table 2. Treatment of Non motor symptoms of PD 


\section{Surgical procedure for the treatment of Parkinson's disease}

The capacity of surgical therapies to provide benefit for patients with PD who can no longer be satisfactorily controlled with medical therapies due to motor complications has been a major advance in the modern treatment of PD (Hallett and Litvan, 2000). Surgical therapies have historically used ablative procedures (e.g., chemical, radiofrequency, or thermal lesions) to make a destructive lesion in overactive or abnormally firing brain targets. However, ablative procedures are associated with the risk of inducing damage to neighboring structures with consequent neurologic dysfunction. The introduction in 1987 of high-frequency deep brain stimulation (DBS) procedures in PD has resolved many of these issues. High frequency stimulation of specific brain targets induces functional benefits that simulate the effects of a destructive lesion, but without the need for making a destructive brain lesion. DBS is performed by implanting an electrode with four contacts into a target site within the brain and connecting it to a pulse generator placed subcutaneously over the chest or abdomen wall. Stimulator settings can be adjusted periodically with respect to electrode configuration, voltage, frequency, and pulse width (Bergman et al, 1990; Olanow et al, 2000).

The mechanism of action of high-frequency DBS is still not clear, even more than 21 years after its introduction. The mechanism is believed to be independent of the target, because DBS mimics the effects of ablation in all targets used to date, but its effects depend on stimulation rather than on the creation of a lesion.

Patients who are thought to benefit from DBS are those affected by clinically diagnosed idiopathic PD, in whom the cardinal symptoms of the disease- bradykinesia, rigidity, and tremor - are likely to be significantly improved (Krack et al, 2003; Deuschl et al, 2006). Those who show improvement with the optimum adjustment of anti-PD drugs or suprathreshold levodopa dose (300 mg per dose) are highly likely to show a similar improvement after optimum placement of the electrodes (Charles et al, 2002). Higher baseline scores on section III (motor) of the unified PD rating scale (UPDRS) and higher baseline levodopa responsiveness are independent predictors of greater change in motor score after surgery. Midline symptoms, dysautonomic symptoms, and gait disturbance unresponsive to levodopa (ie, freezing) are only slightly improved, if at all (Xie et al, 2001).

The different surgical targets exist in the treatment of PDare as follows: - Ventral intermediate (VIM) nucleus of the thalamus: stimulation procedures in this target provide potent antitremor (Narabayashi, 1989) and antidyskinesia (Narabayashi et al, 1984) effect in PD. However, the thalamus is rarely selected as a target site today because similar benefits can be obtained with other targets that are associated with more widespread antiparkinsonian effects. Subthalamic nucleus (STN) or internal segment of the globus pallidus (GPi) - physiologic and metabolic studies indicate that neurons in both the STN and GPi are overactive in PD (Crossman et al, 1985; Mitchell et al, 1989), and that lesions of these structures provide antiparkinsonian benefits in animal models of PD (Bergman et al, 1990; Brotchie et al, 1991; Guridi et al, 1994;). Both ablation and high frequency stimulation of these targets have been shown to provide antiparkinsonian benefits as well as a profound reduction in dyskinesia (especially GPi) in patients with PD. Although the STN is currently the preferred surgical target in most centers, there is no conclusive data indicating that comparable results cannot be obtained with stimulation of the GPi (Follet et al, 2010). Patients undergoing subthalamic stimulation required a lower dose of dopaminergic agents 
than did those undergoing pallidal stimulation.- Pedunculopontine nucleus (PPN) - the PPN is a diffuse nucleus that extends throughout the upper brainstem. Stimulation and lesions in the PPN influence locomotion, and for this reason it has been referred to as the mesencephalic locomotor center (Pahapill and Lozano, 2000). Preliminary studies suggest that stimulation of the PPN may provide locomotor benefits for patients with PD (Stefani et al, 2007). DBS of the PPN is being actively investigated.

Side effects of DBS can be related to the surgical procedure, the device, or to the stimulation. There is a risk of hemorrhage and damage to neighboring brain structures, although risks are less than are seen with ablative procedures, particularly when performed bilaterally (Hallett and Litvan, 2000). Complications associated with the device can be related to infection or mechanical problems (e.g., lead fracture, movement of the electrode, skin erosion), and may require lead removal or reimplantation. Side effects related to stimulation are generally transient and may be controlled by adjusting the stimulation variables. The battery must be periodically replaced.

\section{Recommendations for the management of Parkinson's disease}

The optimal time frame for onset of therapy has not been clearly defined. Once parkinsonian signs start to have an impact on the patient's life, initiation of treatment is recommended. For each patient, the choice between the numerous effective drugs available is based in several factors. These factors include considerations related to the drug (efficacy for symptomatic control of parkinsonism/prevention of motor complications, safety, practicality, costs, etc.), and the patient (symptoms, age, needs, expectations, experience, comorbidity, socioeconomic level, etc.).

Currently, there is no uniform proposal on initiating symptomatic medication for PD. In the past, levodopa was traditionally used to initiate therapy for PD because it was the most effective symptomatic agent, and levodopa is still commonly used as initial therapy by some physicians. Today, many movement disorder neurologists have elected to initiate symptomatic therapy with a dopamine agonist in appropriate patients, and to supplement with levodopa when satisfactory control cannot be attained with dopamine agonist monotherapy. This treatment philosophy is based on the body of laboratory and clinical information indicating that dopamine agonists are associated with a reduced risk of inducing motor complications compared with levodopa. Dopamine agonist use as as initial therapy because they delay the time until levodopa is required and permit use of lower doses of levodopa. To begin with levodopa is the preferred treatment for patients with PD with cognitive impairment, the elderly who have a reduced propensity to develop motor complications, and patients suspected of having an atypical parkinsonism who are undergoing a trial of dopaminergic therapy.

MAO-B inhibitors such as selegiline and rasagiline provide another therapeutic option in early disease. MAO-B inhibitors have been shown to provide modest antiparkinsonian effects when used as monotherapy and also delay the need for levodopa. The symptomatic effect is more modest than that of levodopa and (probably) dopamine agonists, but they are easy to administer (one dose, once daily, no titration). Furthermore the TEMPO and the ADAGIO studies suggest that early treatment with rasagiline provides benefits that cannot be attained with later introduction of the same medication (Parkinson Study Group, 2002; 
Olanow et al, 2009). Although this does not establish neuroprotection and long-term studies are required to determine the effect of the drug on cumulative disability in the long run, it does indicate that earlier treatment with rasagiline may provide a better outcome, at least at the 18-month time point. For these reasons, many physicians now choose to initiate therapy in patients with early PD with an MAO-B inhibitor.

There may be advantages to initiating therapy in patients with early PD with both an MAO$\mathrm{B}$ inhibitor and a dopamine agonist (not at the same time) to enhance clinical benefits and further delay the need for levodopa. However, there have been no studies as yet examining the effects of combining an MAO-B inhibitor with a dopamine agonist on the need for levodopa and the risk of inducing dyskinesia. However, subset analyses in studies testing rasagiline in advanced patients (Parkinson Study Group, 2005; Rascol et al, 2005) and preliminary studies with a new MAO-B inhibitor safinamide, (Stocchi et al, 2004) suggest that adding an MAO-B inhibitor to a dopamine agonist improves UPDRS scores.

Amantadine or anticholinergics are not routinely prescribed in patients with early PD, although some movement disorder specialists might use anticholinergics if tremor is the predominant feature in young patient with PD.

There are a variety of ways to enhance motor response in patients who experience suboptimal motor control with dopamine agonist or levodopa monotherapy. The simplest approach is to gradually raise the dose of the dopaminergic agent. However, high doses of dopamine agonists can be associated with neuropsychiatric side effects, sedation and ICDs. If patients cannot be satisfactorily controlled on an agonist, then levodopa should be added. If the patient is receiving levodopa monotherapy, increased doses might be effective. Higher doses are associated with an increased risk of motor complications, but may be justified if required to provide a satisfactory clinical response. The addition of a dopamine agonist may enhance benefit without increasing the risk of motor complications. COMT and/or MAO-B inhibitors may also be useful in managing patients with a suboptimal clinical response. The use of a subcutaneous apomorphine penject as a rescue device for unpredictable refractory off periods can also be helpful in some instances, and its fast action helps to restore confidence in patients becoming insecure about leaving home (Ostergaard et al, 1995).

Despite adjustments of the timing and dose frequency of levodopa, motor fluctuations and dyskinesias can mark the long-term therapeutic benefit. Amantadine is an effective antidyskinetic agent in some patients. Subcutaneous waking day apomorphine pump is a highly effective treatment for refractory motor fluctuations. Orally administered anti-parkinsonian medication should be adjusted obtain thebest results for dyskinesia reduction and off periods. Enteric administration of a soluble formulation of levodopa (Duodopa) through gastro-jejunostomy is another highly effective medical option for patients who failed to, or are reluctant to, try the apomorphine pump. Infusion therapies is based on the principle that continuous infusion of a dopaminergic agent provides more constant and physiologic activation of striatal dopamine receptors than is accomplished with intermittent administration of the same drug, and thereby reduces the risk of motor complications. Continuous infusion of either levodopa or apomorphine has been tested in patients with advanced PD and consistently been reported to reduce the frequency of motor complications (Manson et al, 2002; Antonini et al, 2007). Sustained improvement in motor performance with a great reduction in drug-induced involuntary movements can also be achieved by functional neurosurgery with bilateral deep brain stimulation of the STN or GPi. 


\section{Experimental approaches}

Cell-based therapies have been studied based on the notion that transplantation of dopaminergic cells could replace dopamine neurons, which degenerate in PD, and restore dopaminergic function in a more physiologic manner than can be achieved with oral therapies (Lindvall and Bjo"rklund, 2004). Fetal nigral transplantation has been the best studied of these approaches to date. Numerous laboratory studies have demonstrated that embryonic dopaminergic neurons implanted into the denervated striatum can survive, extend axons, provide organotypic innervations of the striatum, produce dopamine, and provide behavioral benefits in the 6-OHDA rodent and MPTP-monkey (Olanow et al, 1996). These studies have served as the basis for initiating clinical trials in patients with PD. To date, there is no universal agreement on the optimal transplant protocol. Open-label clinical trials using a variety of different transplant regimens produced variable clinical results. Various types of cells have been used (adrenal gland, mesencephalic fetal grafts, and more recently, epithelial retinal cells). Stem cells are also being investigated, which might be better tolerated immunologically, but raise their own (oncological) problems. Despite the elegance of this approach, it is still experimental and is not currently available to patients (Morizane et al, 2008). Intrastriatal carotid body (CB) transplants have been assayed in animal models of PD to test whether they increase the striatal dopamine levels and/or exert a neuroprotective action on the nigrostriatal pathway. Currently it being studied the in vitro formation of new $C B$ tissue derived from adult $C B$ stem cells, given the limitations of previous studies have been presented with autotransplantation of $C B$ in patients with $P D$ (López-Barneo et al, 2009).

Gene delivery approaches are also being actively investigated as a possible treatment for PD. In this technology, viruses are used as vectors to introduce the DNA of a desired protein into the genome of cells within a specific brain target. Furthermore, promoters can ensure that the virus vector infects specific brain cells (e.g., TH promoter targets dopamine cells). This sequence can thus potentially result in continuous production of the desired therapeutic protein in the desired target region of the brain (Dass et al, 2006). Most human studies have used the adeno-associated virus serotype 2 (AAV-2) as the vector, as AAV-2 does not induce an immune response and permits long-term expression of the transgene. No clinically significant or unanticipated adverse events have been encountered in any of the gene therapy studies performed to date (Svendsen, 2007). Different gene therapy approaches are currently being tested in PD, e.g trophic factors such as glial-derived nerve factor (Lang et al, 2006) or neurturin (Marks et al, 2010).

\section{Conclusions}

The current knowledge of the disease continues to evolve and be challenged by scientific discovery. Further research on the function of the proteins identified by the susceptibility genes, the interplay of the disease process with normal ageing, and the nature of environmental triggers that unmask the disease process will be needed if we are to develop reliable biomarkers and a cure for this disabling movement disorder. Although it is producing significant progress in new therapeutic options important unmet medical needs remain, and even more effective therapeutic interventions are required for the successful management of the patient with PD. Many such agents are now in development. However, future strategies need to focus on more selective targeting of subtypes of neurotransmitter 
receptors to reduce side effects and optimise benefit. Finally, the development of neuroprotective agents in PD has to date focused on preventing dopamine cell loss. However, to be optimally effective, such therapies will also need to target nondopamine cells involved in the multisystem disease process.

\section{References}

[1] Ahlskog JE and Muenter MD(2001). Frequency of levodopa related dyskinesias and motor fluctuations as estimated from the cumulative literature. Movement Disorders 16, 3 (May 2001): 448-458, 0885-3185.

[2] Andersohn F, Garbe E (2009). Cardiac and noncardiac fibrotic reactions caused by ergotand nonergot-derived dopamine agonists. Mov Disord 24, 1(Jan 2009):129-33, 15318257.

[3] Antonini A, Isaias IU, Canesi M, Zibetti M, Mancini F, Manfredi L, Dal Fante M, Lopiano L and Pezzoli G. (2007). Duodenal levodopa infusion for advanced Parkinson's disease: 12- month treatment outcome. Mov Disord 22, 8 (Jun 2008):1145-1149, 08853185.

[4] Assal F, Spahr L, Hadengue A, Rubbia-Brandt L and Burkhard PR (1998). Tolcapone and fulminant hepatitis. Lancet 352, 9132 (Sep 1998):958, 0140-6736.

[5] Ben-Shlomo Y, Churchyard A, Head J, Hurwitz B, Overstall P, Ockelford J and Lees AJ (1998). Investigation by Parkinson's Disease Research Group of United Kingdom into excess mortality seen with combined levodopa and selegiline treatment in patients with early, mild Parkinson's disease: further results of randomized trial and confidential inquiry. British Medical Journal 316, 7139 (Apr 1998): 1191-1196.

[6] Bergman H, Wichmann T and DeLong MR (1990). Reversal of experimental parkinsonism by lesions of the subthalamic nucleus. Science 249, 4975 (Sep 1990): 1436 - 38, 0036-8075.

[7] Biskup S, Gerlach M, Kupsch A, Reichmann H, Riederer P, Vieregge P, Wüllner U and Gasser T. (2008). Genes associated with Parkinson syndrome. J Neuro, 255, 5 (Sep 2008), 8-17, 0340-5354.

[8] Bloem BR, Hausdoroff JM, Visser JE and Giladi N (2004). Falls and freezing of gait in Parkinson 's disease: a review of two interconnected, episodic phenomena. Mov Disord 19, 8 (Aug 2004): 871-84, 0885-3185.

[9] Bonifati V, Rizzu P, van Baren MJ, Schaap O, Breedveld GJ, Krieger E, Dekker MC, Squitieri F, Ibanez P, Joosse M, van Dongen JW, Vanacore N, van Swieten JC, Brice A, Meco G, van Duijn CM, Oostra BA and Heutink P (2003). Mutations in the DJ-1 gene associated with autosomal recessive early-onset parkinsonism. Science 299, 5604 (Jan 2003) :256-259, 1095-9203.

[10] Braak H and Del Tredici K. (2010). Pathophysiology of sporadic Parkinson's disease. Fortschr Neurol Psychiatr, 78, Suppl 1 (Mar 2010), S2-4, 1439-3522.

[11] Bracco F, Battaglia A, Chouza C, , Dupont E, Gershanik O, Marti Masso JF and Montastruc JL (2004); PKDS009 Study Group. The long-acting dopamine receptor agonist cabergoline in early Parkinson's disease: final results of a 5-year, doubleblind, levodopa-controlled study. CNS Drugs 18, 11 (Aug 2004):733-746, 1172-7047.

[12] Brotchie JM, Mitchell IJ, Sambrook MA and Crossman AR (1991). Alleviation of parkinsonism by antagonist of excitatory amino acid transmission in the medial 
segment of the globus pallidus in rat and primate. Mov Disord 6, 2 (Jan 1991): 133$138,0885-3185$.

[13] Brodsky MA, Godbold J, Roth T and Olanow CW (2003). Sleepiness in Parkinson's disease: a controlled study. Mov Disord 18, 6 (June 2003):668-672, 0885-3185.

[14] Butzer JF, Silver DE and Sahs AL (1975). Amantadine in Parkinson's disease. A doubleblind, placebo-controlled, crossover study with long-term follow-up. Neurology 25, 7 (Jul 1975): 603-6, 0028-3878.

[15] Bxarone P, Poewe W, Albrecht S, Debieuvre C, Massey D, Rascol O, Tolosa E, Weintraub D (2010). Pramipexole for the treatment of depressive symptoms in patients with Parkinson's disease: a randomised, double-blind, placebo-controlled trial. Lancet Neurol 9, 6 (Jun 2010): 573-80, 1474-4465.

[16] Cantello R, Riccio A, Gilli M, Delsedime M, Scarzella L, Aguggia M and Bergamasco B. (1986). Bornaprine vs placebo in Parkinson disease: double-blind controlled crossover trial in 30 patients. Ital J Neurol Sci 7, 1 (Feb 1986): 139-43, 0392-0461.

[17] Ceravolo R, Frosini D, Rossi C and Bonuccelli U (2010). Spectrum of addictions in Parkinson's disease: from dopamine dysregulation syndrome to impulse control disorders. J Neurol 257(Suppl 2)(Nov 2010):S276-83, 1432-1459.

[18] Charles PD, Van Blercom N, Krack P, Lee SL, Xie J, Besson G, Benabid AL, Pollak P (2002). Predictors of effective bilateral subthalamic nucleus stimulation for PD. Neurology 59, 6 (Sep 2002): 932-34, 0028-3878.

[19] Chartier-Harlin MC, Kachergus J, Roumier C, Mouroux V, Douay X, Lincoln S, Levecque C, Larvor L, Andrieux J, Hulihan M, Waucquier N, Defebvre L, Amouyel P, Farrer M and Destée A. (2004). Alpha-synuclein locus duplication as a cause of familial Parkinson's disease. Lancet 364, 9440 (Sep 2004),1167-9, 1474-547X.

[20] Chaudhuri KR, Healy DG and Schapira AH (2006). National Institute for Clinical Excellence. Non-motor symptoms of Parkinson' $s$ disease: diagnosis and management. Lancet Neurol 5, 3 (Mar 2006): 235 - 45, 1474-4422.

[21] Chung TH, Deane KH, Ghazi-Noori S, Rickards H and Clarke CE (2003). Systematic review of antidepressant therapies in Parkinson' s disease. Parkinsonism Relat Disord 10, 2 (Dec 2003): 59 - 65, 1353-8020.

[22] Colosimo C, Hughes AJ, Kilford L and Lees AJ. (2003). Lewy body cortical involvement may not always predict dementia in Parkinson's disease. J Neurol Neurosurg Psychiatry 74, 7 (Jul 2003), 852 - 56, 0022-3050.

[23] Comella CL (2007). Sleep disorders in Parkinson' s disease: an overview. Mov Disord 22 (suppl 17)(Sep 2007): S367 - 73, 0885-3185.

[24] Constantinescu R, Romer M, McDermott MP, Kamp C and Kieburtz K; CALM-PD Investigators of the Parkinson Study Group (2007). Impact of pramipexole on the onset of levodopa-related dyskinesias. Mov Disord 22, 9 (Jul 2007):1317- 1319, 15318257.

[25] Corrigan MH, Denahan AQ, Wright CE, Ragual RJ and Evans DL (2000). Comparison of pramipexole, fluoxetine, and placebo in patients with major depression. Depress Anxiety 11, 2 (May 2000): 58-65, 1091-4269.

[26] Crossman AR, Mitchell IJ and Sambrook MA (1985). Regional brain uptake of 2deoxyglucose in N-methyl-4-phenyl-1,2,3,6- tetrahydropyridine (MPTP)-induced 
parkinsonism in the macaque monkey. Neuropharmacology 24, 6 (Jun 1985):587-591, 0028-3908.

[27] Dass B, Olanow CW and Kordower J (2006). Gene transfer of trophic factors and stem cell grafting as treatments for Parkinson's disease. Neurology 66, 10 suppl 4 (May 2006):S89- S103, 1526-632X.

[28] De Lau LM and Breteler MM. (2006). Epidemiology of Parkinson's disease. Lancet Neurol , 5, 6(june 2006), 525-535, 1474-4422.

[29] Damier P, Hirsch EC, Agid Y and Graybiel AM. (1999). The substantia nigra of the human brain. II. Patterns of loss of dopamine-containing neurons in Parkinson 's disease. Brain 122, 8 (Aug 1999), 1437-48, 0006-8950.

[30] Denny AP and Behari M (1999). Motor fluctuations in Parkinson's disease. Journal of the Neurological Sciences 165, 1(May 1999): 18-23, 0022-510X.

[31] De Rijk MC, Breteler MM, Graveland GA, Grobbee DE, van der Meché FG and Hofman A. (1995). Prevalence of Parkinson's disease in the elderly: the Rotterdam Study. Neurology, 45, 12 (Dec 1995), 2143-46, 0028-3878.Di Fonzo A, Dekker MC, Montagna P, Baruzzi A, Yonova EH, Correia Guedes L, Szczerbinska A, Zhao T, DubbelHulsman LO, Wouters CH, de Graaff E, Oyen WJ, Simons EJ, Breedveld GJ, Oostra BA, Horstink MW and Bonifati V (2009). FBXO7 mutations cause autosomal recessive, early-onset parkinsonian-pyramidal syndrome. Neurology 72, 3 (Jan 2009):240-5, 1526-632X.

[32] Deuschl G, Schade-Brittinger C, Krack P, Volkmann J, Schäfer H, Bötzel K, Daniels C, Deutschländer A, Dillmann U, Eisner W, Gruber D, Hamel W, Herzog J, Hilker R, Klebe S, Kloss M, Koy J, Krause M, Kupsch A, Lorenz D, Lorenzl S, Mehdorn HM, Moringlane JR, Oertel W, Pinsker MO, Reichmann H, Reuss A, Schneider GH, Schnitzler A, Steude U, Sturm V, Timmermann L, Tronnier V, Trottenberg T, Wojtecki L, Wolf E, Poewe W and Voges J; German Parkinson Study Group, Neurostimulation Section (2006). A randomized trial of deep-brain stimulation for Parkinson's disease [published erratum in N Engl J Med 355, 9 (Aug 2006): 896-908, 1533-4406.

[33] Emre M, Aarsland D, Albanese A, Byrne EJ, Deuschl G, De Deyn PP, Durif F, Kulisevsky J, van Laar T, Lees A, Poewe W, Robillard A, Rosa MM, Wolters E, Quarg P, Tekin S and Lane R (2004). Rivastigmine for dementia associated with Parkinson's disease. N Engl J Med 351, 24 (Dec 2004):2509-18, 1533-4406.

[34] Etminan M, Samii A, Takkouche B and Rochon P (2001). Increased risk of somnolence with the new dopamine agonists in patients with Parkinson's disease. A metaanalysis of randomised controlled trials. Drug Safety 24, 11 (Oct 2001): 863-868, 0114-5916.

[35] Evans AH, Katzenschlager R, Paviour D, O'Sullivan JD, Appel S, Lawrence AD and Lees AJ (2004). Punding in Parkinson's disease: its relation to the dopamine dysregulation syndrome. Mov Disord 19, 4 (Apr 2004):397-405, 0885-3185.

[36] Fahn S, Oakes D, Shoulson I, Kieburtz K, Rudolph A, Lang A, Olanow CW, Tanner C and Marek K; Parkinson Study Group (2004). Levodopa and the progression of Parkinson's disease. N Engl J Med 351, 24 (Dec 2004): 2498-508, 1533-4406. 
[37] Fernandez HH, Trieschmann ME, Burke MA, Jacques C and Friedman JH (2003). Longterm outcome of quetiapine use for psychosis among Parkinsonian patients. Mov Disord 18; 5 (May 2003):510-4, 0885-3185.

[38] Ferreira JJ, Galitzky M, Montastruc JL and Rascol O (2000). Sleep attacks and Parkinson's disease treatment. Lancet 355, 9212 (Apr 2000):1333-4, 0140-6736.

[39] Follett KA, Weaver FM, Stern M, Hur K, Harris CL, Luo P, Marks WJ Jr, Rothlind J, Sagher O, Moy C, Pahwa R, Burchiel K, Hogarth P, Lai EC, Duda JE, Holloway K, Samii A, Horn S, Bronstein JM, Stoner G, Starr PA, Simpson R, Baltuch G, De Salles A, Huang GD and Reda DJ; CSP 468 Study Group (2010). Pallidal versus subthalamic deep-brain stimulation for Parkinson's disease. N Engl J Med 362, 22 (Jun 2010):2077-91, 1533-4406.

[40] Friedman JH and Factor SA (2000). Atypical antipsychotics in the treatment of druginduced psychosis in Parkinson's disease. Mov Disord 15, 2 (Mar 2000):201-211, 0885-3185.

[41] Frucht S, Rogers JD, Greene PE, Gordon MF and Fahn S (1999). Falling asleep at the wheel: motor vehicle mishaps in persons taking pramipexole and ropinirole. Neurology 52, 9 (Jun 1999): 1908-10, 0028-3878.

[42] Funayama M, Hasegawa K, Kowa H, Saito M, Tsuji S and Obata F (2002). A new locus for Parkinson's disease (PARK8) maps to chromosome 12p11.2-q13.1. Ann Neurol 51, 3 (Mar 2002), 296-301, 0364-5134.

[43] Gilks WP, Abou-Sleiman PM, Gandhi S, Jain S, Singleton A, Lees AJ, Shaw K, Bhatia KP, Bonifati V, Quinn NP, Lynch J, Healy DG, Holton JL, Revesz T and Wood NW. (2005). A common LRRK2 mutation in idiopathic Parkinson' s disease. Lancet 365, 9457(Jan 2005), 415-16, 1474-547X.

[44] Goetz CG, Tanner CM, Shannon KM, Shannon KM and Carroll VS (1988). Controlled release carbidopa/levodopa (CR4-Sinemet) in Parkinson's disease patients with and without motor fluctuations. Neurology 38, 5(May): 1143-1146, 0028-3878.

[45] Gold BG, Nutt JG (2002). Neuroimmunophilin ligands in the treatment of Parkinson's disease. Curr Opin Pharmacol 2, 1 (Feb 2002):82- 86, 1471-4892.

[46] Goldberg MS and Lansbury PT. (2000). Is there a cause-and-effect relationship between alpha-synuclein fibrillization and Parkinson's disease?. Nat Cell Biol 2, 7 (Jul 2000), E115-E119, 1465-7392.

[47] Goldstein DS, Holmes C, Li ST, Bruce S, Metman LV and Cannon RO 3rd (2000). Cardiac sympathetic denervation in Parkinson disease. Ann Intern Med 133, 5 (Sep 2000):338-347, 0003-4819.

[48] Greffard S, Verny M, Bonnet AM, Seilhean D, Hauw JJ and Duyckaerts C. (2010). A stable proportion of Lewy body bearing neurons in the substantia nigra suggests a model in which the Lewy body causes neuronal death. Neurobiol Aging 31, 1(Jan 2010), 99-103, 1558-1497.

[49] Guridi J, Herrero MT, Luquin R, Guillen J and Obeso JA (1994). Subthalamotomy improves MPTP-induced parkinsonism in monkeys. Stereotact Funct Neurosurg 62, 1-4 (Jan 1994): 98-102, 1011-6125.

[50] Hallett M and Litvan I; Members of the Task Force on Surgery for Parkinson's Disease of the American Academy of Neurology Therapeutic and Technology Assessment Committee (2000). Scientific position paper of the Movement Disorder Society 
evaluation of surgery for Parkinson's disease. Mov Disord 15, 3 (May 2000):436-438, 0885-3185.

[51] Halliday G, Hely M, Reid W and Morris J. (2008). The progression of pathology in longitudinally followed patients with Parkinson' s disease. Acta Neuropathol, 115, 4 (Apr 2008), 409-15, 0001-6322.

[52] Hardy J. (2005). Expression of normal sequence pathogenic proteins for neurodegenerative disease contributes to disease risk: permissive templating as a general mechanism underlying neurodegeneration. Biochem Soc Trans 33; 4 (Aug 2005), 578-81, 0300-5127.

[53] Hardy J, Lewis P, Revesz T, Lees A and Paisán-Ruiz. (2009). Genetics of Parkinson's syndromes: a critical review. Curr Opin Genet Dev 19, 3 (Jun 2009), 254-65, 18790380.

[54] Hauser RA, Schapira AH, Rascol O, Barone P, Mizuno Y, Salin L, Haaksma M, Juhel N and Poewe W (2010). Randomized, double-blind, multicenter evaluation of pramipexole extended release once daily in early Parkinson's disease. Mov Disord 25, 15 (Nov 2010):2542-9, 1531-8257.

[55] Healy DG, Falchi M, O'Sullivan SS, Bonifati V, Durr A, Bressman S, Brice A, Aasly J, Zabetian CP, Goldwurm S, Ferreira JJ, Tolosa E, Kay DM, Klein C, Williams DR, Marras C, Lang AE, Wszolek ZK, Berciano J, Schapira AH, Lynch T, Bhatia KP, Gasser T, Lees AJ and Wood NW (2008). Phenotype, genotype, and worldwide genetic penetrance of LRRK2-associated Parkinson's disease: a case-control study. Lancet Neurol 7, 7 (Jul 2008), 583-590, 1474-4422.

[56] Hedrich K, Djarmati A, Schafer N, Hering R, Wellenbrock C, Weiss PH, Hilker R, Vieregge P, Ozelius LJ, Heutink P, Bonifati V, Schwinger E, Lang AE, Noth J, Bressman SB, Pramstaller PP, Riess O and Klein C (2004). DJ-1 (PARK7) mutations are less frequent than Parkin (PARK2) mutations in early-onset Parkinson disease. Neurology 62, 3 (Feb 2004):389-394, 1526-632X.

[57] Heinonen EH and Myllylä V (1998). Safety of selegiline (deprenyl) in the treatment of Parkinson's disease. Drug Saf 19, 1 (Jul 1998): 11-22, 0114-5916.

[58] Iravani MM, Haddon CO, Cooper JM, Jenner P and Schapira AH (2006). Pramipexole protects against MPTP toxicity in nonhuman primates. J Neurochem 96, 5 (Mar 2006):1315-1321, 0022-3042.

[59] Jankovic J, Hunter C (2002). A double-blind, placebo-controlled and longitudinal study of riluzole in early Parkinson's disease. Parkinsonism Relat Disord 8, 4 (Marz 2002): 271-6, 1353-8020.

[60] Katzenschlager R and Lees AJ (2002). Treatment of Parkinson's disease: levodopa as the first choice. Journal of Neurology 249(Suppl. 2)(Sep 2002): II19-II24, 0340-5354.

[61] Katzenschlager R, Head J, Schraq A, Ben-Shlomo Y, Evans A and Lees AJ. Fourteenyear final report of the randomized PDRG-UK trial comparing three initial treatments in PD. Neurology , 71, 7 (Aug 2008), 474-80, 1526-632X.Lashley T, Holton JL, Gray E, Kirkham K, O'Sullivan SS, Hilbig A, Wood NW, Lees AJ and Revesz T. (2008). Cortical alpha-synuclein load is associated with amyloid-beta plaque burden in a subset of Parkinson' s disease patients. Acta Neuropathol, 115, 4 (Apr 2008), 417-25, 0001-6322. 
[62] Keus SH, Bloem BR, Hendriks EJ, Bredero-Cohen AB and Munneke M; Practice Recommendations Development Group (2007). Evidence-based analysis of physical therapy in Parkinson' $\mathrm{s}$ disease with recommendations for practice and research. Mov Disord 22, 4 (Mar 2007): 451-60, 0885-3185.

[63] Khan NL, Graham E, Critchley P, Schrag AE, Wood NW, Lees AJ, Bhatia KP and Quinn N (2003). Parkin disease: a phenotypic study of a large case series. Brain 126, 6 (June 2003), :1279-92, 0006-8950.

[64] Kitada T, Asakawa S, Hattori N, Matsumine H, Yamamura Y, Minoshima S, Yokochi M, Mizuno Y and Shimizu N (1998). Mutations in the parkin gene cause autosomal recessive juvenile parkinsonism. Nature 392, 6676 (Apr 1998):605-8, 0028-0836.

[65] Kleiner-Fisman G and Fisman DN (2007). Risk factors for the development of pedal edema in patients using pramipexole. Arch Neurol 64, 6 (Jun 2007): 820-4, 00039942.

[66] Koller WC, Hutton JT, Tolosa E and Capilldeo R (1999). Immediate-release and controlled-release carbidopa/levodopa in PD: a 5-year randomized multicenter study. Carbidopa/Levodopa Study Group. Neurology 53, 5(Sep 1999): 1012-1019, 0028-3878.

[67] Korczyn AD, Brunt ER, Larsen JP, Nagy Z, Poewe WH and Ruggieri S (1999). A 3-year randomized trial of ropinirole and bromocriptine in early Parkinson's disease. The 053 Study Group. Neurology 53, 2 (Jul 1999): 364-70, 0028-3878.

[68] Kornhuber J, Weller M, Schoppmeyer K and Riederer P (1994). Amantadine and memantine are NMDA receptor antagonists with neuroprotective properties. J Neural Transm 43: 91-104, 0303-6995.

[69] Krack P, Batir A, Van Blercom N, Chabardes S, Fraix V, Ardouin C, Koudsie A, Limousin PD, Benazzouz A, LeBas JF, Benabid AL and Pollak P. (2003). Five-year follow-up of bilateral stimulation of the subthalamic nucleus in advanced Parkinson' s disease. N Engl J Med 349, 20 (Nov 2003): 1925-34, 1533-4406.

[70] Kruger R, Kuhn W, Muller T, Woitalla D, Graeber M, Kosel S, Przuntek H, Epplen JT, Schols L and Riess O. (1998). Ala30Pro mutation in the gene encoding alphasynuclein in Parkinson's disease. Nat Genet 18, 2 (Feb 1998), 106-108, 1061-4036.

[71] Kubo SI, Kitami T, Noda S, Shimura H, Uchiyama Y, Asakawa S, Minoshima S, Shimizu N, Mizuno Y and Hattori N (2001). Parkin is associated with cellular vesicles. J Neurochem 78, 1 (Jul 2001):42-54, 0022-3042.

[72] Kumazawa R, Tomiyama H, Li Y, Imamichi Y, Funayama M, Yoshino H, Yokochi F, Fukusako T, Takehisa Y, Kashihara K, Kondo T, Elibol B, Bostantjopoulou S, Toda T, Takahashi H, Yoshii F, Mizuno Y and Hattori N (2008) Mutation analysis of the PINK1 gene in 391 patients with Parkinson disease. Arch Neurol 65, 6 (Jun 2008):802-808, 1538-3687.

[73] Kurth MC, Adler CH, Hilaire MS, Singer C, Waters C, LeWitt P, Chernik DA, Dorflinger EE and Yoo K (1997). Tolcapone improves motor function and reduces levodopa requirement in patients with Parkinson's disease experiencing motor fluctuations: a multicenter, double-blind, randomized, placebo-controlled trial. Neurology 48, 1 (Jan 1997):81- 87, 0028-3878.

[74] Lang AE, Gill S, Patel NK, Lozano A, Nutt JG, Penn R, Brooks DJ, Hotton G, Moro E, Heywood P, Brodsky MA, Burchiel K, Kelly P, Dalvi A, Scott B, Stacy M, Turner D, 
Wooten VG, Elias WJ, Laws ER, Dhawan V, Stoessl AJ, Matcham J, Coffey RJ and Traub M (2006). Randomized controlled trial of intraputamenal glial cell linederived neurotrophic factor infusion in Parkinson disease. Ann Neurol 59, 3 (Mar 2006):459-466, 0364-5134.

[75] Larsen JP, Worm-Petersen J, Siden A, Gordin A, Reinikainen K and Leinonen M (2003). The tolerability and efficacy of entacapone over 3 years in patients with Parkinson's disease. Eur J Neurol 10, 2 (Mar 2003):137-146,1351-5101.

[76] Lees AJ, Hardy J and Revesz T. (2009). Parkinson's disease. Lancet 373, 9680 (Jun 2009), 2055-2066, 1474-547X.

[77] Li JY, Englund E, Holton JL, Soulet D, Hagell P, Lees AJ, Lashley T, Quinn NP, Rehncrona S, Björklund A, Widner H, Revesz T, Lindvall O and Brundin P. (2008). Lewy bodies in grafted neurons in subjects with Parkinson' $\mathrm{s}$ disease suggest hostto-graft disease propagation. Nat Med 14, 5 (May 2008), 501-03, 1546-170X.

[78] Lemke MR, Brecht HM, Koester J and Reichmann H (2006). Effects of the dopamine agonist pramipexole on depression, anhedonia and motor functioning in Parkinson's disease. J Neurol Sci 248, 1-2 (Oct 2006): 266-70, 0022-510X.

[79] Levy G (2007). The relationship of Parkinson disease with aging. Arch Neurol 64, 9 (Sep 2007): 1242-46, 0003-9942.

[80] Lew MF, Hauser RA, Hurtig HI, Ondo WG, Wojcieszek J, Goren T and Fitzer-Attas CJ. (2010). Long-term efficacy of rasagiline in early Parkinson's disease. Int J Neurosci 120, 6 (Jun 2010): 404-8, 1563-5279.

[81] Li JY, Englund E, Widner H, Rehncrona S, Björklund A, Lindvall O and Brundin P. (2010). Characterization of Lewy body pathology in 12- and 16-year-old intrastriatal mesencephalic grafts surviving in a patient with Parkinson's disease. Mov Disord 25, 8, 1091-06, 1531-8257.

[82] Lindvall O and Bjo“rklund A (2004). Cell therapy in Parkinson's disease. NeuroRx 1, 4 (Oct 2004):382-393, 1545-5343.

[83] Low PA and Singer W (2008). Management of neurogenic orthostatic hypotension: an update. Lancet Neurol 7, 5 (May 2008): 451-58, 1474-4422.

[84] López-Barneo J, Pardal R, Ortega-Sáenz P, Durán R, Villadiego J and Toledo-Aral JJ (2009). The neurogenic niche in the carotid body and its applicability to antiparkinsonian cell therapy. J Neural Transm 116, 8 (Aug 2009):975-82, 1435-1463.

[85] Mamikonyan E, Siderowf AD, Duda JE, Potenza MN, Horn S, Stern MB and Weintraub D (2008). Long-term follow-up of impulse control disorders in Parkinson's disease. Mov Disord 23, 1 (Jan 2008): 75-80, 1531-8257 .

[86] Manson AJ, Turner K and Lees AJ (2002). Apomorphine monotherapy in the treatment of refractory motor complications of Parkinson's disease: long-term follow-up study of 64 patients. Mov Disord 17, 6:1235-41, 0885-3185.

[87] Marks WJ Jr, Bartus RT, Siffert J, Davis CS, Lozano A, Boulis N, Vitek J, Stacy M, Turner D, Verhagen L, Bakay R, Watts R, Guthrie B, Jankovic J, Simpson R, Tagliati M, Alterman R, Stern M, Baltuch G, Starr PA, Larson PS, Ostrem JL, Nutt J, Kieburtz K, Kordower JH and Olanow CW (2010). Gene delivery of AAV2-neurturin for Parkinson's disease: a double-blind, randomised, controlled trial. Lancet Neurol 9, 12 (Dec 2010):1164-72, 1474-4465. 
[88] Mathias CJ, Senard JM, Braune S, Watson L, Aragishi A, Keeling JE and Taylor MD. (2001). L-threodihydroxyphenylserine (L-threo-DOPS; droxidopa) in the management of neurogenic orthostatic hypotension: a multinational, multi-center, dose-ranging study in multiple system atrophy and pure autonomic failure. Clin Auton Res 2001; 11, 4 (Aug 2001): 235-42, 0959-9851.

[89] etman LV, Del Dotto P, LePoole K, Konitsiotis S, Fang J and Chase TN (1999). Amantadine for levodopa-induced dyskinesias: a 1-year follow-up study. Arch Neurol 56, 1 (Nov 1999):1383-1386, 0003-9942.

[90] Meral H, Aydemir T, Ozer F, Ozturk O, Ozben S, Erol C, Cetin S, Hanoglu L, Ozkayran $\mathrm{T}$ and Yilsen M. (2007). Relationship between visual hallucinations and REM sleep behavior disorder in patients with Parkinson's disease. Clin Neurol Neurosurg 109, 10 (Dec 2007):862- 867, 0303-8467.

[91] Mitchell IJ, Clarke CE and Boyce S, Robertson RG, Peggs D, Sambrook MA and Crossman AR (1989). Neural mechanisms underlying parkinsonian symptoms based upon regional uptake of 2-deoxyglucose in monkeys exposed to 1-methyl4-phenyl-1,2,3,6-tetrahydropyridine. Neuroscience 32, 1 (Jan 1989):213-226, 03064522.

[92] Mizuno $\mathrm{Y}$, Kondo $\mathrm{T}$ and Narabayashi $\mathrm{H}$ (1995). Pergolide in the treatment of Parkinson's disease. Neurology 45, 3(Suppl. 31)(Mar 1995): S13-S21, 0028-3878.

[93] Montastruc JL, Rascol O, Senard JM and Rascol A (1994). A randomized controlled study comparing bromocriptine to which levodopa was later added, with levodopa alone in previously untreated patients with Parkinson's disease: a five year follow up. J Neurol Neurosurg Psychiatry 57, 9 (Sep 1994):1034 -1038, 0022-3050.

[94] Montastruc JL, Brefel-Courbon C, Senard JM, Bagheri H, Ferreira J, Rascol O and Lapeyre-Mestre M. (2001) . Sleep attacks and antiparkinsonian drugs: a pilot prospective pharmacoepidemiologic study. Clin Neuropharmacol 24, 3 (May-June 2001):181-183, 0362-5664 .

[95] Morgan JC and Sethi KD (2006). Pergolide-induced ergotism. Neurology 67, 1 (Jul 2006):104, 1526-632X.

[96] Morgenthaler TI, Kapur VK, Brown T, Swick TJ, Alessi C, Aurora RN, Boehlecke B, Chesson AL Jr, Friedman L, Maganti R, Owens J, Pancer J and Zak R; Standards of Practice Committee of the American Academy of Sleep Medicine. (2007). Practice parameters for the treatment of narcolepsy and other hypersomnias of central origin [published erratum in Sleep 2008; 31: TOC]. Sleep 30, 12 (Dec 2007): 1705-11, 0161-8105.

[97] Morizane A, Li JY and Brundin P (2008). From bench to bed: the potential of stem cells for the treatment of Parkinson' s disease. Cell Tissue Res 331, 1 (Jan 2008): 323-36, 1432-0878.

[98] Muller T, Erdmann C, Muhlack S, Bremen D, Przuntek H and Woitalla D (2006). Inhibition of catechol-O-methyltransferase contributes to more stable levodopa plasma levels. Mov Disord 21, 3 (Mar 2006):332-336, 0885-3185.

[99] Neumann J, Bras J, Deas E, O'Sullivan SS, Parkkinen L, Lachmann RH, Li A, Holton J, Guerreiro R, Paudel R, Segarane B, Singleton A, Lees A, Hardy J, Houlden H, Revesz T and Wood NW ( 2009). Glucocerebrosidase mutations in clinical and 
pathologically proven Parkinson's disease. Brain 132, Pt 7 (Jul 2009):1783-94, 14602156.

[100] Narabayashi H, Yokochi F and Nakajima Y (1984). Levodopainduced dyskinesia and thalamotomy. J Neurol Neurosurg Psychiatry 47, 8 (Aug 1984):831- 839, 0022-3050.

[101] Narabayashi H (1989). Stereotaxic vim thalamotomy for treatment of tremor. Eur Neurol 29, (suppl 1)(Jan 1989):29 -32, 0014-3022.

[102] Nirenberg MJ and Waters C (2006). Compulsive eating and weight gain related to dopamine agonist use. Mov Disord 21, 4 (Apr 2006): 524-9, 0885-3185.

[103] Noe E, Marder K, Bell KL, Jacobs DM, Manly JJ and Stern Y (2004). Comparison of dementia with Lewy bodies to Alzheimer's disease and Parkinson's disease with dementia. Mov Disord 19, 1 (Jan 2004):60-67, 0885-3185.

[104] Nutt JG, Woodward WR, Hammerstad JP, Carter JH and Anderson JL (1984). The "onoff " phenomenon in Parkinson's disease. Relation to levodopa absorption and transport. N Engl J Med 310, 8 (Feb 1984):483- 488, 0028-4793.

[105] Nutt JG, Burchiel KJ, Comella CL, Jankovic J, Lang AE, Laws ER Jr, Lozano AM, Penn RD, Simpson RK Jr, Stacy M and Wooten GF; ICV GDNF Study Group. Implanted intracerebroventricular. Glial cell line-derived neurotrophic factor. (2003). Randomized, double-blind trial of glial cell line-derived neurotrophic factor (GDNF) in PD. Neurology 60, 1 (Jan 2003): 69-73, 1526-632X.

[106] Nyholm D, Nilsson Remahl AI, Dizdar N, Constantinescu R, Holmberg B, Jansson R, Aquilonius SM and Askmark H (2005). Duodenal levodopa infusion monotherapy vs oral polypharmacy in advanced Parkinson disease. Neurology 64, 2 (Jan 2005):216-223, 1526-632X.

[107] Oertel WH, Wolters E, Sampaio C, Gimenez-Roldan S, Bergamasco B, Dujardin M, Grosset DG, Arnold G, Leenders KL, Hundemer HP, Lledó A, Wood A, Frewer P and Schwarz J (2006). Pergolide versus levodopa monotherapy in early Parkinson's disease patients: the PELMOPET study. Mov Disord 21, 3 (Mar 2006): 343-353, 08853185.

[108] Olanow CW, Hauser RA, Gauger L, Malapira T, Koller W, Hubble J, Bushenbark K, Lilienfeld D and Esterlitz J (1995). The effect of deprenyl and levodopa on the progression of Parkinson's disease. Ann Neurol 38, 5 (Nov 1995): 771-7, 03645134.

[109] Olanow CW. Selegiline: current perspectives on issues related to neuroprotection and mortality (1996). Neurology 47, (6 suppl 3)(Dec 1996):S210 -S216, 0028-3878.

[110] Olanow CW, Kordower JH and Freeman TB (1996). Fetal nigral transplantation as a therapy for Parkinson's disease. Trends Neurosci 19, 3 (Mar 1996):102-109, 01662236.

[111] Olanow CW, Myllyla VV, Sotaniemi KA, Larsen JP, Pålhagen S, Przuntek H, Heinonen EH, Kilkku O, Lammintausta R, Mäki-Ikola O and Rinne UK (1998). Effect of selegiline on mortality in patients with Parkinson's disease: a meta-analysis. Neurology 51, 3 (Sep 1998): 825-830, 0028-3878.

[112] Olanow CW, Brin M and Obeso JA (2000). The role of deep brain stimulation as a surgical treatment for Parkinson's disease. Neurology 55, 12(suppl 6)(Feb 2000):60$66,0028-3878$. 
[113] Olanow CW, Watts RL and Koller WC (2001). An algorithm (decision tree) for the management of Parkinson's disease: treatment guidelines. Neurology 56, 11 Suppl. 5 (Jun 2001): S1-S88, 0028-3878.

[114] Olanow CW and Stocchi F (2004). COMT inhibitors in Parkinson's disease: can they prevent and/or reverse levodopa induced motor complications? Neurology 62, 1 suppl 1 (Jan 2004):S72-S81, 1526-632X.

[115] Olanow CW, Agid Y, Mizuno Y, Albanese A, Bonuccelli U, Damier P, De Yebenes J, Gershanik O, Guttman M, Grandas F, Hallett M, Hornykiewicz O, Jenner P, Katzenschlager R, Langston WJ, LeWitt P, Melamed E, Mena MA, Michel PP, Mytilineou C, Obeso JA, Poewe W, Quinn N, Raisman-Vozari R, Rajput AH, Rascol O, Sampaio C and Stocchi F(2004). Levodopa in the treatment of Parkinson's disease: current controversies. Movement Disorders 19, 9 (Sep 2004): 997-1005, 08853185.

[116] Olanow CW, Kieburtz K, Stern M, Watts R, Langston JW, Guarnieri M and Hubble J; US01 Study Team (2004). Double-blind, placebo-controlled study of entacapone in levodopa-treated patients with stable Parkinson disease. Arch Neurol 61, 10 (Oct 2004):1563-1568, 0003-9942.

[117] Olanow CW, Schapira AHV, LeWitt PA, Kieburtz K, Sauer D, Olivieri G, Pohlmann H and Hubble J(2006). TCH346 as a neuroprotective drug in Parkinson's disease: a double-blind, randomised, controlled trial. Lancet Neurol 5, 12 (Dec 2006):10131020, 1474-4422.

[118] Olanow CW, Rascol O, Hauser R, Feigin PD, Jankovic J, Lang ALangston W, Melamed E, Poewe W, Stocchi F and Tolosa E; ADAGIO Study Investigators (2009) . A double-blind, delayed-start trial of rasagiline in Parkinson's disease. $N$ Engl J Med 361, 13 (Sep 2009): 1268-78, 1533-4406.

[119] Olanow CW, Stern MB and Sethi K. (2009). The scientific and clinical basis for the treatment of Parkinson disease. Neurology, 26, 72(21 Suppl 4)(Dec 2009), S1-136, 0028-3878.

[120] Ostergaard L, Werdelin L, Odin P, Lindvall O, Dupont E, Christensen PB, Boisen E, Jensen NB, Ingwersen S and, Schmiegelow M (1995). J Neurol Neurosurg Psychiatry 58, 6 (Jun 1995):681-7, 0022-3050.

[121] Pahwa R, Stacy MA, Factor SA, Lyons KE, Stocchi F, Hersh BP, Elmer LW, Truong DD and Earl NL; EASE-PD Adjunct Study Investigators. (2007). Ropinirole 24-hour prolonged release: randomized, controlled study in advanced Parkinson disease. Neurology 68, 14 (Apr 2007): 1108-15, 1526-632X.

[122] Pahapill PA and Lozano AM (2000). The pedunculopontine nucleus and Parkinson's disease. Brain 123, 9 (Sep 2000):1767-1783, 0006-8950.

[123] Paisan-Ruiz C, Jain S, Evans EW, Gilks WP, Simon J, van der Brug M, Lopez de Munain A, Aparicio S, Gil AM, Khan N, Johnson J, Martinez JR, Nicholl D, Carrera IM, Pena AS, de Silva R, Lees A, Marti-Masso JF, Perez-Tur J, Wood NW and Singleton AB (2004) Cloning of the gene containing mutations that cause PARK8linked Parkinson's disease. Neuron 44, 18 (Nov 2004), 595-600, 0896-6273.

[124] Paisán-Ruiz (2009). LRRK2 gene variation and its contribution to Parkinson disease. Hum Mutat 30, 8 (Aug 2009): 1153-60, 1098-1004. 
[125] Paisán-Ruiz C, Guevara R, Federoff M, Hanagasi H, Sina F, Elahi E, Schneider SA, Schwingenschuh P, Bajaj N, Emre M, Singleton AB, Hardy J, Bhatia KP, Brandner S, Lees AJ, and Houlden H (2010). Early-onset L-dopa-responsive parkinsonism with pyramidal signs due to ATP13A2, PLA2G6, FBXO7 and spatacsin mutations. Mov Disord 25, 12 (Sep 2010): 1791-800, 1531-8257.

[126] Parkinson J. An Essay on the Shaking Palsy. London: Whittingham and Rowland for Sherwood, Neely and Jones; 1817.

[127] Parkkinen L, Kauppinen T, Pirttila T, Autere JM and Alafuzoff I (2005). Alphasynuclein pathology does not predict extrapyramidal symptoms or dementia. Ann Neurol 57, 1 (Jan 2005), 82 - 91, 0364-5134.

[128] Parkinson Study Group (1993). Effects of tocopherol and deprenyl on the progression of disability in early Parkinson's disease. N Engl J Med 328, 21 (Jan 1993:176 -183, 0028-4793.

[129] Parkinson Study Group (1996). Impact of deprenyl and tocopherol treatment on Parkinson's disease in DATATOP subjects not requiring levodopa. Ann Neurol 39, 1 (Jan 1996): 29-36, 0364-5134.

[130] Parkinson Study Group (1997). Entacapone improved motor fluctuations in levodopatreated Parkinson's disease patients. Ann Neurol 42, 5(Nov 1997):747-755, 03645134.

[131] Parkinson Study Group (1999). Low dose clozapine for the treatment of drug-induced psychosis in Parkinson's disease. N Engl J Med 340, 10 (Mar 1999):757-763, 00284793.

[132] Parkinson Study Group (2000). Pramipexole vs levodopa as initial treatment for Parkinson disease: a randomized controlled trial. Parkinson Study Group. JAMA 284, 15 (Oct 2000): 1931-8, 0098-7484.

[133] Parkinson Study Group (2002). Dopamine transporter brain imaging to assess the effects of pramipexole vs levodopa on Parkinson disease progression. JAMA 287, 13 (Jul 2002): 1653-61, 0098-7484.

[134] Parkinson Study Group (2002). A controlled trial of rasagiline in early Parkinson disease: the TEMPO Study. Arch Neurol 59, 12 (Dec 2002): 1937-43, 0003-9942.

[135] Parkinson Study Group (2005). A randomized placebo-controlled trial of rasagiline in levodopa-treated patients with Parkinson disease and motor fluctuations: the PRESTO study. Arch Neurol 62, 2 (Feb 2005):241-248, 0003-9942.

[136] Parkinson Study Group PRECEPT Investigators (2007). Mixed lineage kinase inhibitor CEP-1347 fails to delay disability in early Parkinson disease. Neurology 2007;69, 15 (Oct 2007):1480- 1490, 1526-632X.

[137] Paus S, Brecht HM, Köster J, Seeger G, Klockgether T and Wüllner U (2003). Sleep attacks, daytime sleepiness, and dopamine agonists in Parkinson's disease. Mov Disord 18, 6(Jun 2003):659-67, 0885-3185.

[138] Polymeropoulos MH, Lavedan C, Leroy E, Ide SE, Dehejia A, Dutra A, Pike B, Root H, Rubenstein J, Boyer R, Stenroos ES, Chandrasekharappa S, Athanassiadou A, Papapetropoulos T, Johnson WG, Lazzarini AM, Duvoisin RC, Di Iorio G and Nussbaum RL. (1997). a- Synuclein gene identified in families with Parkinson's disease. Science 276, 5321 (June 1997), 2045-2047, 0036-8075. 
[139] Porter B, Macfarlane R and Walker R (2008). The frequency and nature of sleep disorders in a community-based population of patients with Parkinson's disease. Eur J Neurol 15, 1 (Jan 2008):50 -54, 1468-1331.

[140] Postuma RB, Lang AE, Massicotte-Marquez J and MontplaisirJ (2006). Potential early markers of Parkinson disease in idiopathic REM sleep behavior disorder. Neurology 66, 6 (Mar 2006):845- 851, 1526-632X.

[141] Pramstaller PP, Schlossmacher MG, Jacques TS, Scaravilli F, Eskelson C, Pepivani I, Hedrich K, Adel S, Gonzales-McNeal M, Hilker R, Kramer PL and Klein C . (2005). Lewy body Parkinson' $\mathrm{s}$ disease in a large pedigree with 77 Parkin mutation carriers. Ann Neurol 58: 3 (Sep 2005), 411-22, 0364-5134.

[142] Rajput AH (2001). Levodopa prolongs life expectancy and is non-toxic to substantia nigra. Parkinsonism Relat Disord 8, 2 (Oct 2001): 95-100, 1353-8020.

[143] Rakshi JS, Pavese N, Uema T, Ito K, Morrish PK, Bailey DL and Brooks DJ. (2002). A comparison of the progression of early Parkinson's disease in patients started on ropinirole or L-dopa: an 18F-dopa PET study. J Neural Transm; 109, 12 (Dec 2002): 1433-43, 0300-9564.

[144] amirez A, Heimbach A, Grundemann J, Stiller B, Hampshire D, Cid LP, Goebel I, Mubaidin AF, Wriekat AL, Roeper J, Al-Din A, Hillmer AM, Karsak M, Liss B, Woods CG, Behrens MI, Kubisch C (2006) Hereditary parkinsonism with dementia is caused by mutations in ATP13A2, encoding a lysosomal type 5 P-type ATPase. Nat Genet 38, 10 (Oct 2008):1184-1191, 1061-4036.

[145] Rascol O, Brooks DJ, Korczyn AD, De Deyn PP, Clarke CE and Lang AE (2000). A fiveyear study of the incidence of dyskinesia in patients with early Parkinson's disease who were treated with ropinirole or levodopa. 056 Study Group. N Engl J Med 342, 20 (May 2000): 1484-91, 0028-4793.

[146] Rascol O, Brooks DJ, Melamad E, Oertel W, Poewe W, Stocchi F and Tolosa E: LARGO study group. (2005). Rasagiline as an adjunct to levodopa in patients with Parkinson's disease and motor fluctuations (LARGO, Lasting effect in Adjunct therapy with Rasagiline Given Once daily, study): a randomised, double-blind, parallel-group trial. Lancet 2005;365, 9463 (Mar 2005):947-954, 1474$547 X$.

[147] Ravina B, Putt M, Siderowf A, Farrar JT, Gillespie M, Crawley A, Fernandez HH, Trieschmann MM, Reichwein S and Simuni T (2005). Donazepil for dementia in Parkinson's disease: a randomized, double blind, crossover study. J Neurol Neurosurg Psychiatry 76, 7 (Jul 2005):934 -939, 0022-3050.

[148] Renkwalder C, Kies B, Rudzinsca M, Fine J, Nikl J, Honczarenco K, et al. Rotigotine effects on early morning motor function and sleep in Parkinson's disease: a dobleblind, randomized, placebo-controlled study (RECOVER). Mov Disord 2010. [Epub ahead of print]

[149] Rinne UK, Bracco F, Chouza C, Dupont E, Gershanik O, Marti Masso JF, Montastruc JL and Marsden CD (1998). Early treatment of Parkinson's disease with cabergoline delays the onset of motor complications. The PKDS009 Study Group. Drugs 1998; 55(Suppl. 1)(Mar 1998): 23-30, 0012-6667. 
[150] Ritter JL and Alexander B (1997). Retrospective study of selegiline antidepressant drug interactions and a review of the literature. Ann Clin Psychiatry 9, 1 (Mar 1997): 7-13, 1040-1237.

[151] Rogaeva E, Johnson J, Lang AE, Gulick C, Gwinn-Hardy K, Kawarai T, Sato C, Morgan A, Werner J, Nussbaum R, Petit A, Okun MS, McInerney A, Mandel R, Groen JL, Fernandez HH, Postuma R, Foote KD, Salehi-Rad S, Liang Y, Reimsnider S, Tandon A, Hardy J, St George- Hyslop P and Singleton AB (2004). Analysis of the PINK1 gene in a large cohort of cases with Parkinson disease. Arch Neurol 61, 12(Dec 2004):1898-1904, 0003-9942.

[152] Roth BL (2007). Drugs and valvular heart disease. N Engl J Med 356, 1 (Jan 2007):6 -9, 1533-4406.

[153] Shin N, Jeong H, Kwon J, Heo HY, Kwon JJ, Yun HJ, Kim CH, Han BS, Tong Y, Shen J, Hatano T, Hattori N, Kim KS,Chang S, Seol W (2008). LRRK2 regulates synaptic vesicle endocytosis. Exp Cell Res 314, 10 (Jun 2008),2055-2065, 1090-2422.

[154] Sagi Y, Mandel S, Amit T and Youdim MB (2007). Activation of tyrosine kinase receptor signaling pathway by rasagiline facilitates neurorescue and restoration of nigrostriatal dopamine neurons in post-MPTP-induced parkinsonism. Neurobiol Dis 25, 1 (Jan 2007): 35-44, 0969-9961.

[155] Schapira AH (2002). Dopamine agonists and neuroprotection in Parkinson's disease. Eur J Neurol 9(suppl 3)(Nov 2002):7-14, 1351-5101.

[156] Shults CW, Oakes D, Kieburtz K, Beal MF, Haas R, Plumb S, Juncos JL, Nutt J, Shoulson I, Carter J, Kompoliti K, Perlmutter JS, Reich S, Stern M, Watts RL, Kurlan R, Molho E, Harrison M and Lew M; Parkinson Study Group (2002). Effects of coenzyme Q10 in early Parkinson disease: evidence of slowing of the functional decline. Arch Neurol 59, 10 (Oct 2002): 1541-50, 0003-9942.

[157] Sidransky E, Nalls MA, Aasly JO, Aharon-Peretz J, Annesi G, Barbosa ER, Bar-Shira A, Berg D, Bras J, Brice A, Chen CM, Clark LN, Condroyer C, De Marco EV, Dürr A, Eblan MJ, Fahn S, Farrer MJ, Fung HC, Gan-Or Z, Gasser T, Gershoni-Baruch R, Giladi N, Griffith A, Gurevich T, Januario C, Kropp P, Lang AE, Lee-Chen GJ, Lesage S, Marder K, Mata IF, Mirelman A, Mitsui J, Mizuta I, Nicoletti G, Oliveira C, Ottman R, Orr-Urtreger A, Pereira LV, Quattrone A, Rogaeva E, Rolfs A, Rosenbaum H, Rozenberg R, Samii A, Samaddar T, Schulte C, Sharma M, Singleton A, Spitz M, Tan EK, Tayebi N, Toda T, Troiano AR, Tsuji S, Wittstock M, Wolfsberg TG, Wu YR, Zabetian CP, Zhao Y and Ziegler SG (2009). Multicenter analysis of glucocerebrosidase mutations in Parkinson's disease. $N$ Engl J Med 361, 17 (Oct 2009):1651-61. 1533-4406.

[158] Singleton AB, Farrer M, Johnson J, Singleton A, Hague S, Kachergus J, Hulihan M, Peuralinna T, Dutra A, Nussbaum R, Lincoln S, Crawley A, Hanson M, Maraganore D, Adler C, Cookson MR, Muenter M, Baptista M, Miller D, Blancato J, Hardy J and Gwinn- Hardy K. (2003). Alpha-Synuclein locus triplication causes Parkinson's disease. Science 302, 5646 (Oct 2003), 841, 1095-9203.

[159] Singleton A, Gwinn-Hardy K, Sharabi Y, Li ST, Holmes C, Dendi R, Hardy J, Singleton A, Crawley A and Goldstein DS. (2004). Association between cardiac denervation and parkinsonism caused by alpha-synuclein gene triplication. Brain 127(Pt 4):768772, 0006-8950. 
[160] Smith LA, Jackson MJ, Al-Barghouthy G, Rose S, Kuoppamaki M, Olanow W and Jenner P (2005). Multiple small doses of levodopa plus entacapone produces continuous dopaminergic stimulation and reduces dyskinesia induction in MPTPtreated drug naïve primates. Mov Disord 20, 3(Mar 2005): 306-14, 0885-3185.

[161]Spillantini MG, Schmidt ML, Lee VM, Trojanowski JQ, Jakes R and Goedert M. (1997). Alpha-synuclein in Lewy bodies. Nature, 388, 6645 (Aug 1997), 839-840, 0028-0836.

[162] Starkstein SE, Mayberg HS, Leiguarda R, Preziosi TJ and Robinson RG (1992). A prospective longitudinal study of depression, cognitive decline, and physical impairments in patients with Parkinson's disease. J Neurol Neurosurg Psychiatry 55, 5 (May 1992):377-82, 0022-3050.

[163] Staskin DR (2006). Trospium chloride: distinct among other anticholinergic agents available for the treatment of overactive bladder. Urol Clin North Am 33, 4 (Nov 2006): 465 - 73, 0094-0143.

[164] Stefani A, Lozano AM, Peppe A, , Stanzione P, Galati S, Tropepi D, Pierantozzi M, Brusa L, Scarnati E and Mazzone P. (2007). Bilateral deep brain stimulation of the pedunculopontine and subthalamic nuclei in severe Parkinson's disease. Brain 130, 6 (Jun 2007):1596 -1607, 1460-2156.

[165] Stocchi F, Arnold G, Onofrj M, Kwiecinski H, Szczudlik A, Thomas A, Bonuccelli U, Van Dijk A, Cattaneo C, Sala P, Fariello RG; Safinamide Parkinson's Study Group (2004). Improvement of motor function in early Parkinson disease by safinamide. Neurology 63, 4 (Aug 2004):746 -748, 1526-632X.

[166] Stocchi F, Rascol O, Kieburtz K, Poewe W, Jankovic J, Tolosa E, Barone P, Lang AE and Olanow CW (2010). Initiating levodopa/carbidopa therapy with and without entacapone in early Parkinson disease: the STRIDE-PD study. Ann Neurol 68, 1 (Jul 2010): 18-2, 1531-8249.

[167] Svendsen C (2007). The first steps towards gene therapy for Parkinson's disease. Lancet Neurol 6, 9 (Sep 2007):754 -756, 1474-4422.

[168] Tandberg E, Larsen MD and Karlsen MD (1999). Excessive daytime sleepiness and sleep benefit in Parkinson's disease: a community-based study. Mov Dis 14, 6 (Nov 1999):922-927, 0885-3185.

[169] Timberlake WH and Vance MA (1978). Four-year treatment of patients with parkinsonism using amantadine alone or with levodopa. Ann Neurol 3, 2 (Feb 1978): 119-28, 0364-5134.

[170] Tolosa E, Gaig C, Santamaría J, Compta Y (2009). Diagnosis and the premotor phase of Parkinson disease. Neurology 72(7 Suppl)(Feb 2009):S12-20, 1526-632X.

[171] Trenkwalder C, Kies B, Rudzinsca M, Fine J, Nikl J, Honczarenco K, Dioszeghy P, Hill D, Anderson T, Myllyla V, Kassubek J, Steiger M, Zucconi M, Tolosa E, Poewe W, Surmann E, Whitesides J, Boroojerdi B and Chaudhuri KR; Recover Study Group. (2010). Rotigotine effects on early morning motor function and sleep in Parkinson's disease: a doble-blind, randomized, placebo-controlled study (RECOVER). Mov Disord 26, 1 (Jan 2011):90-9, 1531-8257.

[172] Valente EM, Abou-Sleiman PM, Caputo V, Muqit MM, Harvey K, Gispert S, Ali Z, Del Turco D, Bentivoglio AR, Healy DG, Albanese A, Nussbaum R, GonzálezMaldonado R, Deller T, Salvi S, Cortelli P, Gilks WP, Latchman DS, Harvey RJ, 
Dallapiccola B, Auburger G and Wood NW (2004). Hereditary early-onset Parkinson's disease caused by mutations in PINK1. Science 304, 5674 (May 2004):1158-60, 1095-9203.

[173] Van de Warrenburg BP, Lammens M, Lucking CB, Denèfle P, Wesseling P, Booij J, Praamstra P, Quinn N, Brice A and Horstink MW. (2001). Clinical and pathologic abnormalities in a family with parkinsonism and parkin gene mutations. Neurology 56, 4 (Feb 2001), 555-57, 0028-3878.

[174] Van Herwaarden G, Berger HJ and Horstink MW (1993). Short-term memory in Parkinson's disease after withdrawal of long-term anticholinergic therapy. Clin Neuropharmacol 16, 5 (Oct 1993): 438-43, 0362-5664.

[175] Vendette M, Gagnon JF, De'cary A, Massicotte-Marquez J, Postuma RB, Doyon J, Panisset M and Montplaisir J (2007). REM sleep behavior disorder predicts cognitive impairment in Parkinson disease without dementia. Neurology 69, 19 (Nov 2007):1843-1849, 1526-632X.

[176] Verhagen Metman L, Del Dotto P, van den Munckhof P, Fang J, Mouradian MM and Chase TN (1998). Amantadine as treatment for dyskinesias and motor fluctuations in Parkinson's disease. Neurology 50, 5 (May 1998):1323-26, 0028-3878.

[177] Voon V, Hassan K, Zurowski M, Duff-Canning S, de Souza M, Fox S, Lang AE and Miyasaki J (2006). Prospective prevalence of pathological gambling and medication association in Parkinson disease. Neurology 66, 11(Jun 2006):1750-52, 1526-632X.

[178] Voon V, Sohr M, Lang AE, Potenza MN, Siderowf AD, Whetteckey J, Weintraub D, Wunderlich GR and Stacy M (2011). Impulse control disorders in parkinson disease: A multicenter case-control study. Ann Neurol [Epub ahead of print].

[179] Waters CH, Kurth M, Bailey P, Shulman LM, LeWitt P, Dorflinger E, Deptula D and Pedder S. (1997). Tolcapone in stable Parkinson's disease: efficacy and safety of long term treatment. The Tolcapone Stable Study Group. Neurology 49, 3 (Sep 1997):665- 671, 0028-3878.

[180] Weintraub D, Morales KH, Moberg PJ, Bilker WB, Balderston C, Duda JE, Katz IR and Stern MB (2005). Antidepressant studies in Parkinson' s disease: a review and meta-analysis. Mov Disord 20, 9 (Sep 2005): 1161-69, 0885-3185.

[181] Weintraub D, Siderowf AD, Potenza MN, Goveas J, Morales KH, Duda JE, Moberg PJ and Stern MB (2006). Association of dopamine agonist use with impulse control disorders in Parkinson disease. Arch Neurol 63, 7(Jul 2006): 969-73, 0003-9942.

[182] Whone AL, Watts RL, Stoessl AJ, Davis M, Reske S, Nahmias C, Lang AE, Rascol O, Ribeiro MJ, Remy P, Poewe WH, Hauser RA and Brooks DJ (2003). Slower progression of Parkinson'sdisease with ropinirole versus levodopa: The REAL-PET study. Ann Neurol 54, 1 (Jul 2003): 93-101, 0364-5134.

[183] Witjas T, Kaphan E, Azulay JP, Blin O, Ceccaldi M, Pouget J, Poncet M and Chérif AA (2002). Nonmotor fluctuations in Parkinson's disease: frequent and disabling. Neurology 59, 3 (Aug 2002):408-413, 0028-3878.

[184] Xie J, Krack P, Benabid AL and Pollak P (2001). Effect of bilateral subthalamic nucleus stimulation on parkinsonian gait. J Neurol 248, 12 (Dec 2001): 1068-72, 0340-5354. 
[185] Zanettini R, Antonini A, Gatto G, Gentile R, Tesei S and Pezzoli G (2007). Valvular heart disease and the use of dopamine agonists for Parkinson's disease. N Engl J Med 356, 1 (Jan 2007):39-46, 1533-4406.

[186] Zarranz JJ, Alegre J, Gomez-Esteban JC, Lezcano E, Ros R, Ampuero I, Vidal L, Hoenicka J, Rodriguez O, Atares B, Llorens V, Gomez Tortosa E, del Ser T, Munoz DG and de Yebenes JG. (2004). The new mutation, E46K, of alpha-synuclein causes Parkinson and Lewy body dementia. Ann Neurol 55, 2 (Feb 2004), 164-173, 03645134.

[187] Zimprich A, Biskup S, Leitner P, Lichtner P, Farrer M, Lincoln S, Kachergus J, Hulihan M, Uitti RJ, Calne DB, Stoessl AJ, Pfeiffer RF, Patenge N, Carbajal IC, Vieregge P, Asmus F, Muller-Myhsok B, Dickson DW, Meitinger T, Strom TM, Wszolek ZK and Gasser T (2004) Mutations in LRRK2 cause autosomal-dominant parkinsonism with pleomorphic pathology. Neuron 44, 4 (Nov 2004), 601-607, 0896-6273.

[188] Zhu W, Xie W, Pan T, Jankovic J, Li J, Youdim MB, Le W (2008). Comparison of neuroprotective and neurorestorative capabilities of rasagiline and selegiline against lactacystin-induced nigrostriatal dopaminergic degeneration. J Neurochem 2008; 105, 5 (Jun 2008): 1970-8, 1471-4159. 


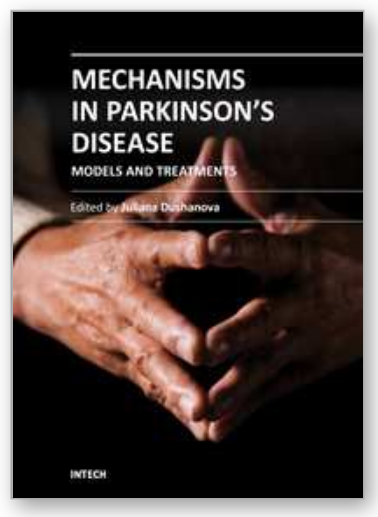

\author{
Mechanisms in Parkinson's Disease - Models and Treatments \\ Edited by Dr. Juliana Dushanova
}

ISBN 978-953-307-876-2

Hard cover, 582 pages

Publisher InTech

Published online 08, February, 2012

Published in print edition February, 2012

Parkinson's disease (PD) results primarily from the death of dopaminergic neurons in the substantia nigra. Current PD medications treat symptoms; none halt or retard dopaminergic neuron degeneration. The main obstacle to developing neuroprotective therapies is a limited understanding of the key molecular mechanisms that provoke neurodegeneration. The discovery of PD genes has led to the hypothesis that misfolding of proteins and dysfunction of the ubiquitin-proteasome pathway are pivotal to PD pathogenesis. Previously implicated culprits in PD neurodegeneration, mitochondrial dysfunction, and oxidative stress may also act in part by causing the accumulation of misfolded proteins, in addition to producing other deleterious events in dopaminergic neurons. Neurotoxin-based models have been important in elucidating the molecular cascade of cell death in dopaminergic neurons. PD models based on the manipulation of PD genes should prove valuable in elucidating important aspects of the disease, such as selective vulnerability of substantia nigra dopaminergic neurons to the degenerative process.

\title{
How to reference
}

In order to correctly reference this scholarly work, feel free to copy and paste the following:

Fátima Carrillo and Pablo Mir (2012). Update in Parkinson's Disease, Mechanisms in Parkinson's Disease Models and Treatments, Dr. Juliana Dushanova (Ed.), ISBN: 978-953-307-876-2, InTech, Available from: http://www.intechopen.com/books/mechanisms-in-parkinson-s-disease-models-and-treatments/update-inparkinson-s-disease

\section{INTECH}

open science | open minds

\section{InTech Europe}

University Campus STeP Ri

Slavka Krautzeka 83/A

51000 Rijeka, Croatia

Phone: +385 (51) 770447

Fax: +385 (51) 686166

www.intechopen.com

\section{InTech China}

Unit 405, Office Block, Hotel Equatorial Shanghai

No.65, Yan An Road (West), Shanghai, 200040, China

中国上海市延安西路65号上海国际贵都大饭店办公楼 405 单元

Phone: +86-21-62489820

Fax: $+86-21-62489821$ 
(C) 2012 The Author(s). Licensee IntechOpen. This is an open access article distributed under the terms of the Creative Commons Attribution 3.0 License, which permits unrestricted use, distribution, and reproduction in any medium, provided the original work is properly cited. 